\title{
Swelling of cell walls in mature sweet cherry fruit: factors and mechanisms
}

\author{
Christine Schumann ${ }^{1} \cdot$ Moritz Knoche $^{1} \mathbb{1}$
}

Received: 27 August 2019 / Accepted: 30 January 2020 / Published online: 14 February 2020

(c) The Author(s) 2020

\begin{abstract}
Main conclusion Swelling of sweet cherry cell walls is a physical process counterbalanced by turgor. Cell turgor prevents swelling in intact cells, whereas loss of turgor allows cell walls to swell.
\end{abstract}

\begin{abstract}
Swelling of epidermal cell walls precedes skin failure in sweet cherry (Prunus avium) cracking. Swollen cell walls lead to diminished cell:cell adhesions. We identify the mechanism of cell wall swelling. Swelling was quantified microscopically on epidermal sections following freeze/thaw treatment or by determining swelling pressure or swelling capacity of cell wall extracts. Releasing turgor by a freeze/thaw treatment increased cell wall thickness 1.6 -fold within $2 \mathrm{~h}$. Pressurizing cell wall extracts at $>12 \mathrm{kPa}$ prevented swelling in water, while releasing the pressure increased swelling. The effect was fully reversible. Across cultivars, cell wall thickness before and after turgor release in two subsequent seasons was significantly correlated (before release of turgor: $r=0.71^{* *}, n=14$; after release of turgor: $r=0.73^{* *}, n=14$ ) as was the swelling of cell walls upon turgor release $\left(r=0.71^{* *}, n=14\right)$. Close relationships were also identified for cell wall thickness of fruit of the same cultivars grown in the greenhouse and the field (before release of turgor: $r=0.60, n=10$; after release of turgor: $\left.r=0.78^{* *}, n=10\right)$. Release of turgor by heating, plasmolysis, incubation in solvents or surfactants resulted in similar swelling (range $2.0-3.1 \mu \mathrm{m}$ ). Cell wall swelling increased from 1.4 to $3.0 \mu \mathrm{m}$ as $\mathrm{pH}$ increased from $\mathrm{pH} 2.0$ to 5.0 but remained nearly constant between pH 5.0 and 8.0. Increasing ethanol concentration decreased swelling. Swelling of sweet cherry cell walls is a physical process counterbalanced by turgor.
\end{abstract}

Keywords Cell wall swelling $\cdot$ Cracking $\cdot$ Epidermis $\cdot$ Pectin $\cdot$ Prunus avium $\cdot$ Splitting

$\begin{array}{ll}\text { Abbreviations } \\ \text { AIR } & \text { Alcohol-insoluble residue } \\ \text { ES } & \text { Epidermal skin section(s) } \\ \text { PEG } & \text { Polyethylene glycol } \\ \text { SC } & \text { Swelling capacity }\end{array}$

\section{Introduction}

Rain cracking severely limits the production of many soft, fleshy, fruit species in all regions of the world where rain occurs during the harvest period. Sweet cherries (Prunus avium) and grapes (Vitis vinifera) are prominent examples of

Moritz Knoche

moritz.knoche@obst.uni-hannover.de

1 Institute for Horticultural Production Systems, Leibniz-University Hannover, Herrenhäuser Straße 2, 30419 Hannover, Germany high-value crops in which rain cracking can be commercially devastating — but there are many others, including tomatoes (Solanum lycopersicum), blueberries (Vaccinium corymbosum) and plums (Prunus $\times$ domestica).

The primary cause of rain cracking in a fleshy fruit has for many years been thought to be an excessive internal (tissue) pressure (Considine and Kriedemann 1972; Sekse et al. 2005; Measham et al. 2009), where this excessive pressure is a direct result of osmotic water uptake through the fruit's rain-wetted skin. Thus, the fruit has been assumed to resemble a thin-walled pressure vessel containing a solution rich in osmotically active carbohydrates. The very negative osmotic potential of this solution is the driving force for the osmotic uptake of surface water. The increase in fruit volume and surface area occasioned by water uptake increases the tissue pressure ('turgor') inside the fruit. The fruit is believed to crack when certain critical thresholds of turgor and/or of skin strain are exceeded (Considine and Kriedemann 1972; Andersen and 
Richardson 1982; Measham et al. 2009). Thus, what we shall refer to as the 'critical turgor/strain' hypothesis offers an intuitively plausible explanation of fruit cracking and, moreover, it is consistent with the observation that rain cracking usually follows extended periods of surface wetness after rainfall and/or dew. However, in recent years, an increasing body of experimental evidence has started to bring this old hypothesis into question. More recently, still it has led to its rejection among many researchers. For a review, see Knoche and Winkler (2017).

The 'zipper' hypothesis offers an alternative understanding that remains consistent with the general phenomenological observations - cracking is associated with rain/dewwetted fruit skin-but is also consistent with a new body of careful experimental data which does not align well with the 'critical turgor/strain' hypothesis (Knoche and Winkler 2017). Cracking is now considered to be a multistep process comprising: (i) the formation of microcracks due to cuticular strain caused by downregulation of cutin and wax synthesis and deposition during early growth (Knoche et al. 2004; Peschel and Knoche 2005; Alkio et al. 2012) and the later exposure of the strained cuticle to wetness (Knoche and Peschel 2006), (ii) localized water penetration through microcracks (Winkler et al. 2016), (iii) the bursting of individual mesocarp cells and the consequent leakage of malic acid into the cell-wall-free space that further damages adjacent cells including those of the epidermis (Winkler et al. 2015; Grimm et al. 2019), and (iv) the complete loss of the (already low) turgor that results in cell wall swelling (Grimm and Knoche 2015). Lastly, cell wall swelling decreases cell wall stiffness, fracture tension and cell:cell adhesion resulting in the separation of neighboring cells (Brüggenwirth and Knoche 2017). The tension generated by the skin strain is sufficient to cause cells to separate along their swollen walls and to rupture the skin. Thus, the skin 'unzips'-that is, starting from a single-point failure, a skin crack propagates linearly in a manner similar to the opening up of a garment with a 'zipper' and somewhat analogous to the propagation of a 'ladder' in a piece of knitted fabric (Grimm et al. 2019). Based on the 'zipper' hypothesis, the swelling of cell walls is an essential part of the decrease in the fracture stress and in cell:cell adhesion. The swelling of cell walls is also a key textural characteristic of fleshy fruit that develops a desirable 'melting' texture during ripening (Redgwell et al. 1997). Little is known about cell wall swelling in sweet cherry.

The objectives of our study were (i) to characterize swelling of epidermal cell walls in sweet and sour cherries and (ii) to identify the underlying mechanism(s). These steps are a prerequisite for identifying the cell wall fraction responsible for cell wall swelling. A better understanding of cell wall swelling may be helpful in developing strategies to counter the cracking of fleshy fruit by a combination of breeding and cultural means.

\section{Materials and methods}

\section{Plant material}

Sweet cherry fruit (Prunus avium L.) of 14 cultivars ('Adriana', 'Burlat', 'Dönissens Gelbe', 'Earlise', 'Fabiola', 'Hedelfinger', 'Kordia', 'Merchant', 'Regina', 'Sam', 'Samba', 'Schneiders Späte', 'Staccato' and 'Sweetheart') and sour cherry fruit (Prunus cerasus) of 2 cultivars ('Achat' and 'Morellenfeuer') were harvested at commercial maturity. The stage of maturity was judged based on fruit size and color by our experienced workers at the Horticultural Research Station of the Leibniz University in Ruthe (lat. $52^{\circ} 14^{\prime} \mathrm{N}$, long. $9^{\circ} 49^{\prime} \mathrm{E}$ ) over two growing seasons. The growing conditions differed between the two season. In 2015, average temperatures in the field in May and June were lower by 3.3 and $1.7^{\circ} \mathrm{C}$ than in 2016 , respectively, the July temperatures were about similar. Average temperatures in August 2015 were warmer by $1.5^{\circ} \mathrm{C}$ than in 2016 . The sweet cherries were grafted on 'Gisela 5' rootstocks (Prunus cerasus $\times P$. canescens) and the sour cherries on 'Maxma Delbard' rootstocks ( $P$. avium $\times$ P. mahaleb). The trees were cultivated either under a rain cover in the field or in a greenhouse. Mean temperatures in the greenhouse were higher by $1.6^{\circ} \mathrm{C}$ and $1.1{ }^{\circ} \mathrm{C}$ in the 2015 and 2016 growing season as compared to the field. There was no application of foliage applied $\mathrm{Ca}$ fertilizers in either season at either site. Unless otherwise stated, fruit were processed fresh on the day of sampling or stored at $-20{ }^{\circ} \mathrm{C}$ until cell-wall extraction. In addition, off-season 'Lapins' sweet cherries from New Zealand (2016) and 'Santina' sweet cherry from Chile (2019) were purchased locally. All fruits were selected for uniformity of development based on size and color and for freedom from visual defects.

\section{Microscopy}

To determine cell wall swelling, epidermal skin sections (ES) were prepared, usually from the equatorial plane of the cheek. Narrow strips of skin were excised using parallel razor blades ( $3 \mathrm{~mm}$ between blades). The ES were then pared down from the inner surface, to remove much of the cortical tissue. The ES were carefully blotted using soft tissue paper, transferred immediately to the stage of a microscope (BX-60; Olympus, Hamburg, Germany), placed in a droplet of test solution (usually a $10 \mathrm{mM}$ MES solution at $\mathrm{pH}$ 5.8) and viewed at a magnification of $40 \times$. Calibrated digital photographs (camera: DP73; Olympus) were taken and the thickness of the anticlinal cell walls quantified by image analysis (cellSens; Olympus Soft Imaging Solutions, Münster, Germany). This measurement reflects the initial cell wall thickness between two living turgid cells, 
and before the imposition of any treatment (' + turgor'). This measurement-protoplast to protoplast—included the cell walls of two abutting cells, plus the intervening middle lamella. Cell wall thickness was later re-measured following treatment to minimize turgor ('- turgor') and to maximize cell wall swelling (a freeze/thaw treatment for a minimum of $12 \mathrm{~h}$ at $-20{ }^{\circ} \mathrm{C}$ followed by (usually) $48 \mathrm{~h}$ equilibration at room temperature). The only exceptions were experiments on the effects of plasmolysis (Fig. 6, Table 4), ethanol concentration (Fig. 9), temperature and turgor removal (Table 3) which were carried out without the freeze/thaw treatment. A total of $10 \mathrm{ES}$ were prepared per treatment (1 ES from each of 10 fruit), 2 micrographs were taken per ES, and 2 cell walls were measured per micrograph, such that the total number of cell wall thickness measurements was 40 per treatment. Cell wall swelling ( $\Delta$ thickness) was calculated by subtracting cell wall thickness immediately after excision ('+ turgor') from that $48 \mathrm{~h}$ after the freeze/thaw treatment ('- turgor'). Thus, cell wall swelling represented the increase in thickness of two abutting cell walls plus that of the intervening middle lamella.

\section{Experiments}

The time course of cell wall swelling was measured on microscopic images of ES prepared from 'Burlat' and 'Lapins' fruit directly after excision $(0 \mathrm{~h})$. Thereafter, half of the ES were subjected to a freeze/thaw treatment at $-20{ }^{\circ} \mathrm{C}$ overnight to eliminate turgor. Following thawing at ambient temperature $\left(23^{\circ} \mathrm{C}\right)$, cell wall thickness was determined at $0.5,2,4,8,24,48,78$ and $144 \mathrm{~h}$. The other half of the sample remained without a freeze/thaw treatment. Here, the ES were incubated in deionized water and cell wall thickness was determined after 2, 4, 8, 24, 56, 96, 120 and $144 \mathrm{~h}$ of incubation ('control'). Because the loss of turgor is a prerequisite for cell wall swelling, only cell walls between two non-turgid cells were measured in the control. The only exceptions were those ES that were inspected immediately after excision $(0 \mathrm{~h})$.

Swelling of cell walls in different regions of the fruit surface was studied by preparing ES from the shoulder, cheek, suture or the stylar scar region of 'Lapins' fruit.

The effect of turgor on cell wall swelling was established in 'Sam' by eliminating cell turgor. Turgor was eliminated by one of four methods: (i) destroying membrane integrity by a freeze/thaw treatment $\left(16 \mathrm{~h}\right.$ at $-20{ }^{\circ} \mathrm{C}$ followed by incubation at room temperature for $48 \mathrm{~h}$ ); (ii) plasmolyzing cells in $2.5 \mathrm{M}$ glucose for $24 \mathrm{~h}$ or (iii) solubilizing plasma membranes in either acetone or $20 \mathrm{mM}$ sodium dodecyl sulfate (SDS) for $48 \mathrm{~h}$. In addition, a role of enzymatic activity in cell wall swelling was investigated by denaturation of proteins by heating the ES for $1 \mathrm{~h}$ to $60{ }^{\circ} \mathrm{C}$ followed by $48 \mathrm{~h}$ incubation at room temperature.
This treatment also destroyed cell turgor. Another set of ES were incubated for $48 \mathrm{~h}$ at room temperature without any pretreatment; these served as controls.

The effects of fruit mass loss during storage $\left(2{ }^{\circ} \mathrm{C}\right.$, $95 \% \mathrm{RH}, 35 \mathrm{~d}$ ) on cell wall swelling were established in 'Merchant'.

The relationship between turgor and cell wall swelling was studied in ES excised from 'Staccato'. Turgor was varied by incubating ES in $0,0.25,0.5,0.75,1.0$ or $1.5 \mathrm{M}$ sucrose solutions for $48 \mathrm{~h}$. The percentage of plasmolyzed cells and cell wall thickness were determined by microscopy for each sucrose concentration. A cell was counted as plasmolyzed when the symplast began to detach from the cell wall. The osmotic potential at $50 \%$ plasmolysis and that at $50 \%$ cell wall swelling were calculated using a sigmoidal regression model.

The reversibility of cell wall swelling was studied in a two-phase experiment using 'Santina' sweet cherry. Following measurement of initial cell wall thickness, phase I of the experiment was initiated by incubating ES in hypotonic $(0.25 \mathrm{M},-0.6 \mathrm{MPa})$ or hypertonic sucrose solutions for $22 \mathrm{~h}$ (1.25 M, - 4.8 MPa). Incubation in hypertonic solutions induced plasmolysis in all cells. Cells of ES incubated in hypotonic solutions remained largely turgescent. For phase II of the experiment, half of the ES from the hypertonic sucrose solution (phase I) were transferred to a hypotonic solution and vice versa. Incubation was continued for a further $22 \mathrm{~h}$. For the remaining half of the ES incubation continued in the same solution as during phase I. Incubation in deionized water served as control. Cell wall thickness was quantified after $22 \mathrm{~h}$ (end of phase I) and after $44 \mathrm{~h}$ (end of phase II).

Whether cell wall thickness is affected by exposure to juice from the same fruit was assessed in ES excised from 'Adriana'. Cell wall thickness was quantified after excision and after incubation in juice extracted from the same batch of fruit using a spaghetti press. In addition, ES were incubated in an 'artificial juice' comprising the major osmolytes of sweet cherry juice (Herrmann 2001). These osmolytes were glucose $(277 \mathrm{mM})$, fructose $(253 \mathrm{mM})$, sorbitol (49 mM), potassium malate $(36 \mathrm{mM})$ and malic acid $(9 \mathrm{mM})$. Together, these account for about $98 \%$ of the osmolarity of the juice. Osmolarities were measured by vapor pressure osmometry (VAPRO® 5520 and 5560; Wescor, Logan, UT, USA). To separate the effect of juice from a potential $\mathrm{pH}$ effect, artificial juice was prepared without malic acid. Furthermore, the $\mathrm{pH}$ of the natural juice was adjusted to $\mathrm{pH} 6.4$ using $\mathrm{KOH}$. Cell wall thickness was quantified after excision ('+ turgor') and after a freeze/thaw treatment followed by $48 \mathrm{~h}$ incubation in the respective juices ('- turgor'). Deionized water served as control.

The effect of organic acids on cell wall swelling was investigated in 'Adriana'. Cell wall thickness was quantified 
after excision of the ES. The ES were then incubated in oxalic, tartaric, malic, citric and ascorbic acid (all at $20 \mathrm{mM}$, all solutions prepared in $10 \mathrm{mM}$ MES at $\mathrm{pH}$ 5.8). An MES buffer treatment without addition of acid served as control. Thereafter, the ES were subjected to a freeze/thaw cycle. Following a $48 \mathrm{~h}$ equilibration period, cell wall thickness was quantified again. The effect of $\mathrm{pH}$ on cell wall swelling was investigated in 'Adriana' fruit. The ES were incubated in $10 \mathrm{mM}$ MES buffer with $\mathrm{pH}$ adjusted to $\mathrm{pH} 2,3$, 4, 5, 6, 7 and 9 using $\mathrm{HCl}($ all $\mathrm{pH} \leq 4)$ or $\mathrm{KOH}$ (all $\mathrm{pH}>4$ ). Thereafter, the effect of different buffers on cell wall swelling was studied at constant $\mathrm{pH}$. The ES were incubated in citrate, phosphate, HEPES, MES and TRIS buffer (all at $10 \mathrm{mM}$ ) at $\mathrm{pH}$ 6.7. The $\mathrm{pH}$ was adjusted using $\mathrm{HCl}$ or $\mathrm{KOH}$. Separate ES incubated in deionized water served as controls. Cell wall thicknesses after excision ('+ turgor') and after a freeze/thaw treatment followed by $48 \mathrm{~h}$ of incubation ('- turgor') were quantified and cell wall swelling calculated as described earlier.

The effect of ethanol concentration on cell wall thickness was determined using ES and extracted cell walls prepared from 'Sweetheart'. In phase I of the experiment, 20 skin sections were prepared from 10 fruits. Cell wall thickness was determined after excision and after incubation in $0,25,50$, $75,87.5$ and $99.8 \%$ aqueous ethanol for $48 \mathrm{~h}$. For the subsequent phase II, half the sections were transferred from the initial incubation solution to $99.8 \%$ ethanol. The other half were transferred into $100 \%$ deionized water. All were again incubated for $48 \mathrm{~h}$ and cell wall thickness re-determined.

The effect of temperature on cell wall swelling was studied in 'Merchant' ES incubated in $10 \mathrm{mM}$ MES at $4{ }^{\circ} \mathrm{C}$ or at $23{ }^{\circ} \mathrm{C}$ for $48 \mathrm{~h}$.

The effect of the molar mass $\left(\mathrm{g} \mathrm{mol}^{-1}\right)$ and concentration $\left(\mathrm{g} \mathrm{kg}^{-1}\right.$ ) of polyethylene glycols (PEGs) on the thickness of cell walls was estimated in ES from 'Staccato'. Initial cell wall thickness was measured ( $n=50$ fruit with four cell walls measured per image). The cell wall thickness so obtained, represented the native thickness of fully turgid cells. Thereafter, fruit were incubated in solutions of PEGs of mean molar mass: $300,600,1000,1500,3350$ and $6000 \mathrm{~g} \mathrm{~mol}^{-1}$ of $0,100,200,300,350,400,450$ or $500 \mathrm{~g} \mathrm{~kg}^{-1}$. Sucrose solutions at comparable osmolarities served as controls. The osmolarities of all solutions were measured by vapor pressure osmometry. Following a freeze/thaw treatment to destroy turgor, and after $48 \mathrm{~h}$ of incubation, cell wall thickness was re-determined according to the procedure described above. The osmotic potential at half maximum swelling was calculated for the different PEG molecules from a non-linear regression line fitted through a plot of cell wall swelling vs. osmotic potential. In addition, swelling was expressed as a function of the concentration of ethylene glycol units for all PEG molecules, at all PEG concentrations.

\section{Preparation of extracted cell walls}

Extracted cell walls were prepared using the protocol by Sozzi et al. (2002) with minor modifications. Pedicel and pit were removed from ten frozen fruit and the remaining tissue homogenized in $4 \mathrm{ml}$ per $\mathrm{g}$ tissue of $80 \%$ ( $\mathrm{v} / \mathrm{v}$ ) ice cold ethanol for $2 \mathrm{~min}$. The homogenate was boiled for $30 \mathrm{~min}$, cooled and then filtered through glass filter paper (Whatman GF/C; Sigma-Aldrich, St. Louis, MO, USA). The insoluble material was washed with $95 \%(\mathrm{v} / \mathrm{v})$ ethanol and filtered again, then extracted with $3 \mathrm{ml}$ per $\mathrm{g}$ tissue of chloroform:methanol $(1: 1, \mathrm{v} / \mathrm{v})$ for $15 \mathrm{~min}$, filtered and washed again with the same solvent mixture followed by a final washing step with acetone. The resulting alcohol insoluble residue (AIR) was dried overnight, weighed and stored over dry silica gel until further usage.

\section{Determination of swelling pressure}

To quantify the pressure generated by swelling cell walls the following procedure was developed. A $25 \mathrm{mg}$ sample of AIR was transferred to a custom-built pressure chamber. This chamber had an inner diameter of $25.5 \mathrm{~mm}$ and a port in the base for drainage covered by a stainless steel frit. Wetting of the AIR in the pressure chamber was achieved using $70 \%(\mathrm{v} / \mathrm{v})$ aqueous ethanol and a mild vacuum of $20 \mathrm{kPa}$ for $10 \mathrm{~min}$. Earlier experiments established that there is no cell wall swelling when incubating ES in $70 \%$ aqueous ethanol. The pressure chamber was positioned under a universal material testing machine (BXC-FR2.5TN; ZwickRoell GmbH \& Co. KG, Ulm, Germany) equipped with a $50 \mathrm{~N}$ force transducer (KAP-Z; ZwickRoell). A second stainless steel frit ( $25.4 \mathrm{~mm}$ diameter) was fitted to the force transducer. This frit served as a plunger to pressurize the cell wall in the pressure chamber. To reproducibly determine the minimum volume $\left(V_{\min }\right)$ of the hydrated and non-swollen cell wall, the AIR was pressurized with $10.3 \mathrm{kPa}$ for $12 \mathrm{~h}$ at the onset of each experiment and the $V_{\min }$ was read. After $10 \mathrm{~min}$, the supernatant containing $70 \%$ aqueous ethanol was replaced by the same volume of deionized water. Swelling was quantified by reducing the pressure stepwise: 9.9, $4.9,2.0,1.0,0.5-0.2 \mathrm{kPa}$. The pressure was held constant at each step for $12 \mathrm{~h}$. Preliminary experiments established this time was required to approach an equilibrium volume of swollen cell walls at each pressure. During the experiment, the position of the plunger was recorded by the distance transducer of the universal testing machine. From the position of the plunger, the volume change $(\Delta V)$ due to cell 
wall swelling was calculated as the difference between the volume at a particular pressure minus the minimum volume $\left(V_{\min }\right)$. The swelling pressure $\left(P_{0}\right)$ of the AIR was calculated as the $x$-intercept of a plot of the change in volume $(\Delta V)$ at equilibrium at each pressure vs. the natural logarithm of the applied pressure. The determination of swelling pressure was carried out with three replications.

In a second run of the experiment, the $70 \%$ aqueous ethanol was not removed from the supernatant. The volumes resulting from stepwise releases of pressure were recorded as described before. Here, the equilibration time was set at $6 \mathrm{~h}$. The experiment was conducted in triplicate.

Whether swelling of AIR is reversible was investigated by subjecting extracted cell walls to ascending and descending pressures. During phase I, pressure was decreased stepwise as described above. In phase II, pressure was increased again using the same pressure steps as in phase I. The treatments were repeated during the subsequent phases III and IV. The volumes of the cell wall extracts at anyone pressure were recorded with an equilibration time of $6 \mathrm{~h}$ and the $(\Delta V)$ and the swelling pressures for phases I-IV calculated as described above. The experiment was conducted in triplicate.

\section{Determination of swelling capacity (SC)}

The swelling capacity (SC) of the AIR is an established characteristic to quantify cell wall swelling (Raghavendra et al. 2004; Basanta et al. 2014). Here, we followed the procedure described by Raghavendra et al. (2004) and Basanta et al. (2014) with minor modifications. The AIR was ground thoroughly using a pestle and mortar. A sample of $50 \mathrm{mg}$ $( \pm 0.1 \mathrm{mg})$ of AIR was weighed into a graduated conical tube and $7.5 \mathrm{ml}$ of degassed $10 \mathrm{mM}$ MES (pH 5.8) was added. To ensure thorough wetting and remove all air, the AIR was vacuum infiltrated three times for 10 min each at $3 \mathrm{kPa}$. Following an $18 \mathrm{~h}$ incubation at $22{ }^{\circ} \mathrm{C}$ to reach equilibrium swelling, the final volume of the swollen cell wall was read and the SC was calculated as follows:

$\mathrm{SC}\left(\mathrm{mlg}^{-1}\right)=\frac{\text { Volume of swollen } \mathrm{AIR}(\mathrm{ml})}{\text { Original sample dry weight }(\mathrm{g})}$.

The SC determinations were always carried out with three replications.

The effect of different ethanol concentrations on swelling of the AIR was studied. The AIR was prepared from the same batch of 'Sweetheart' fruit as that investigated in the microscopy assay. The AIR was incubated in $0,25,50,75$ and $100 \%$ of aqueous ethanol for $18 \mathrm{~h}$. The swelling capacity was calculated as described below.

\section{Data analyses}

The data presented in the tables and figures represent the arithmetic means and standard errors. Where error bars are not visible in figures, they are smaller than the data symbols. Data were examined by analysis of variance (AOV) followed by mean comparisons using Tukey's Studentized range test at $p<0.05$ with $\mathrm{R}$ (packet multcomp 1.4-0, procedure glht, R 3.0.2; R Foundation for Statistical Computing, Vienna, Austria). Linear and non-linear regression analysis was conducted using R (packet multcomp 1.4-0, procedure $1 \mathrm{~m}$ and nls). Significance of coefficients of correlation $(r)$ and determination $\left(R^{2}\right)$ at $p<0.05,0.01$ or 0.001 is indicated by $*, * *$ or $* * *$, respectively.

\section{Results}

Increasing percentages of epidermal cells collapsed when skin segments were incubated in deionized water. This was indexed by loss of anthocyanins from the vacuoles (Fig. 1). The cell walls between pairs of collapsed (non-turgid) cells began to swell. Thickness of cell walls between collapsed cells did not differ from those in tissue that had lost turgor following membrane damage caused by a freeze/thaw treatment (data not shown).

A time course study of cell wall swelling following loss of turgor caused by a freeze/thaw treatment established that swelling was rapid. Within $24 \mathrm{~h}$, cell wall swelling had approached an asymptote averaging $5.4 \mu \mathrm{m}$ (Fig. 2). This represents a $61 \%$ increase in cell wall thickness compared with that for turgid cells before the freeze/thaw treatment. To ensure equilibrium swelling in all subsequent comparisons, we chose a standard equilibration time of $48 \mathrm{~h}$ after turgor removal.

When extracted cell walls were pressurized to $10.3 \mathrm{kPa}$, their change in volume was as depicted in Fig. 3a. This pressure was selected, because it corresponds to the mean turgor reported for mature sweet cherry fruit (Schumann et al. 2014). When holding this pressure for $12 \mathrm{~h}$, there was no further detectable increase in volume, indicating that swelling had reached equilibrium (Fig. 3a). When cell walls were incubated in water (but not when incubated in $70 \%$ aqueous ethanol, Fig. 3c), stepwise releases of pressure resulted in corresponding stepwise increases in cell wall volume (Fig. 3b). The relationship between the change in cell wall volume $(\Delta V)$ and the natural logarithm of the applied pressure was linear (Fig. 3d). From this relationship, the pressure required to prevent swelling $\left(P_{0}\right)$ was estimated at $\approx 12 \mathrm{kPa}$ $\left(R^{2}=0.99\right.$; Fig. 3d). 

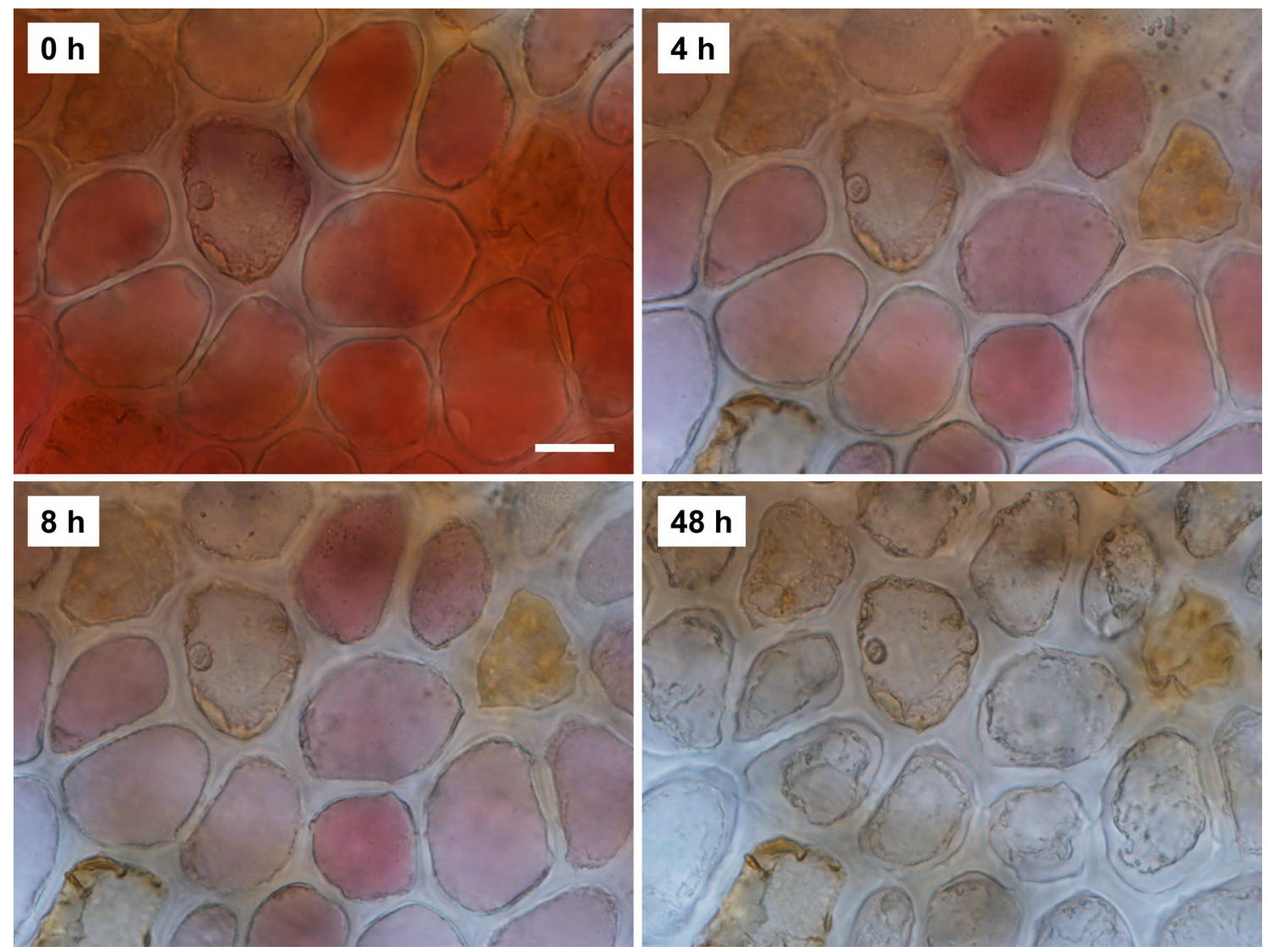

Fig. 1 Micrographs of a time course of change in cell wall thickness of anticlinal walls of epidermal cells of mature 'Lapins' sweet cherry after incubation in deionized water for $0,4,8$ or $48 \mathrm{~h}$. Bar $=20 \mu \mathrm{m}$

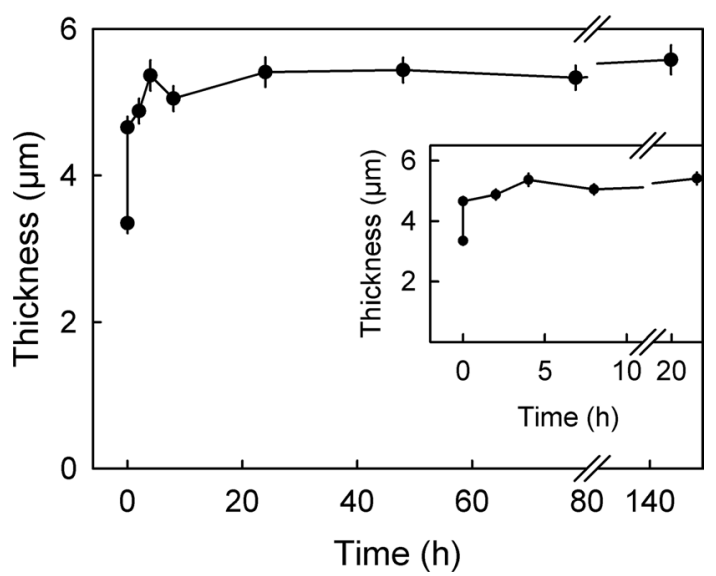

Fig. 2 Time course of change in thickness of anticlinal epidermal cell walls of mature 'Burlat' sweet cherry skin sections. Main graph: long-term time course. Inset: short-term time course. Data are redrawn from main graph but on a different scale. The increase in thickness was monitored after releasing turgor by a freeze/thaw treatment $(n=40)$
Ascending and descending pressure had the same effect on cell wall swelling regardless of whether these were applied during the first cycle (phases I and II) or the second cycle (phases III and IV) (Fig. 4). There was no significant difference in swelling pressure between ascending and descending pressures during the first or second cycle (Fig. 4c).

Significant differences in cell wall thickness and swelling were detected between different sweet cherry cultivars. Swelling was largest in 'Staccato' and lowest in 'Dönissens Gelbe' (Table 1). There were no consistent differences between the sweet and the sour cherries in the extent of cell wall swelling with turgor release.

Across cultivars, cell wall thickness and cell wall swelling following turgor release were significantly correlated between different seasons (Fig. 5a, b). Also, cell wall thickness did not differ significantly between greenhouse-grown fruit and rain-shelter-grown fruit, i.e. cell wall thickness data from the two sites were closely related (Fig. 5c). The 
Fig. 3 Swelling of extracted cell walls of mature 'Staccato' sweet cherry when incubated in deionized water $(\mathbf{a}, \mathbf{b}, \mathbf{d})$ or in ethanol $(\mathbf{c})$. Swelling was quantified as the change in volume $(\Delta V)$ at different pressures $(P)$ using a custom-built pressure chamber. Extracted cell wall was incubated in water to induce swelling. The volume of swollen cell walls after loading the cell wall with different pressures was quantified. a Time course of water-induced swelling of cell walls at a pressure of $10.3 \mathrm{kPa}$. b, $\mathbf{c}$ Representative test program to monitor the increase in volume of extracted cell walls when decreasing the applied pressure stepwise from 10.3 to $0.1 \mathrm{kPa}$. At any one pressure step, pressure was held constant for $12 \mathrm{~h} \mathrm{(a)} \mathrm{or} 6 \mathrm{~h}$ (c) to allow for equilibration of cell wall swelling. d Relationship between the swelling of cell walls $(\Delta V)$ at equilibrium and the applied pressure. The swelling pressure $P_{0}$ corresponds to the pressure at which no swelling occurs. The value $P_{0}$ was estimated as the $x$-intercept of a regression line fitted through a plot of $\Delta V$ vs. $\ln P$. The regression equation was $\Delta V=-0.054( \pm 0.002) * \ln P(\mathrm{kPa})+0.132( \pm 0.003), R^{2}=0.99 * * *$. Data in $\mathbf{a}, \mathbf{b}$ and $\mathbf{c}$ represent a single replicate, those in $\mathbf{d}$ means $\pm \mathrm{SE}$, $n=3$

increase in cell wall thickness was independent of the initial cell wall thickness (Fig. 5d).

Cell wall swelling was greater in the stylar scar region than in the cheek, suture or shoulder regions (Table 2).

There was little difference in the extent of cell wall swelling among the various methods used to release turgor (Table 3). Thus, significant swelling occurred following release of turgor by: freeze/thaw, heating to $60^{\circ} \mathrm{C}$, plasmolysis, or incubation in acetone or in SDS surfactant.

Incubation of ES in sucrose solutions of decreasing (increasingly negative) osmotic potential caused progressive increases in plasmolysis (Fig. 6a). ES incubated in deionized water but not those in sucrose solutions lost vitality as indexed by a coagulated cytoplasm and the absence of an intact vacuole. Incubation in sucrose solutions increased cell wall swelling markedly when osmotic potential was more negative than about $-2 \mathrm{MPa}$ (Fig. 6b; Table 4). There was no difference in cell wall swelling between ES incubated in deionized water and those incubated in solutions having an osmotic potential below - 2 MPa Fig. 6b; Table 4). The fraction of cells plasmolyzed increased as the osmotic potential of the incubation solution decreased (Fig. 6c). The values of osmotic potential corresponding to $50 \%$ cell wall swelling and to $50 \%$ plasmolysis were estimated at -2.0 and - 1.3 MPa, respectively. Deplasmolysing cells by transferring ES from a hypertonic into a hypotonic sucrose solution decreased cell wall thickness to the level not significantly different from the thickness immediately after excision of the ES (Table 4). Thus, the increase in cell wall thickness upon plasmolysis was completely reversible (Table 4 ).

Fruit weight loss during a 35 day storage period had no significant effect on cell wall thickness or on cell wall swelling (following turgor release) (Fig. 7).
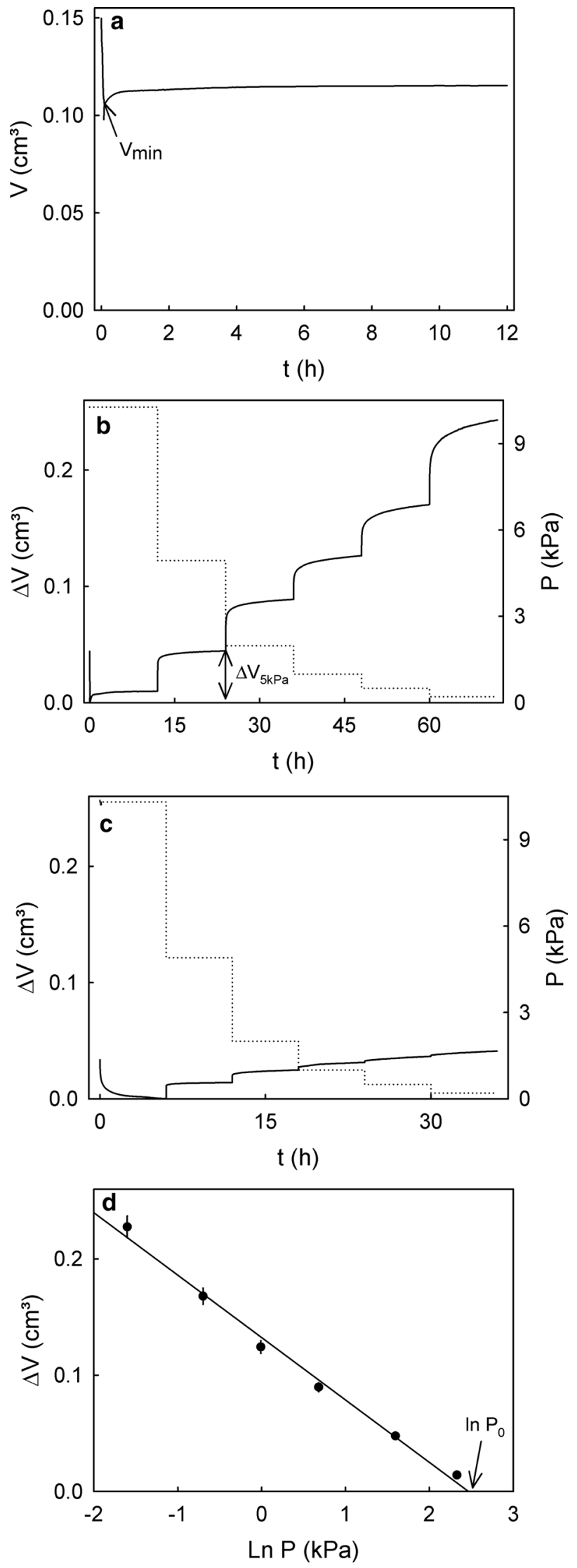

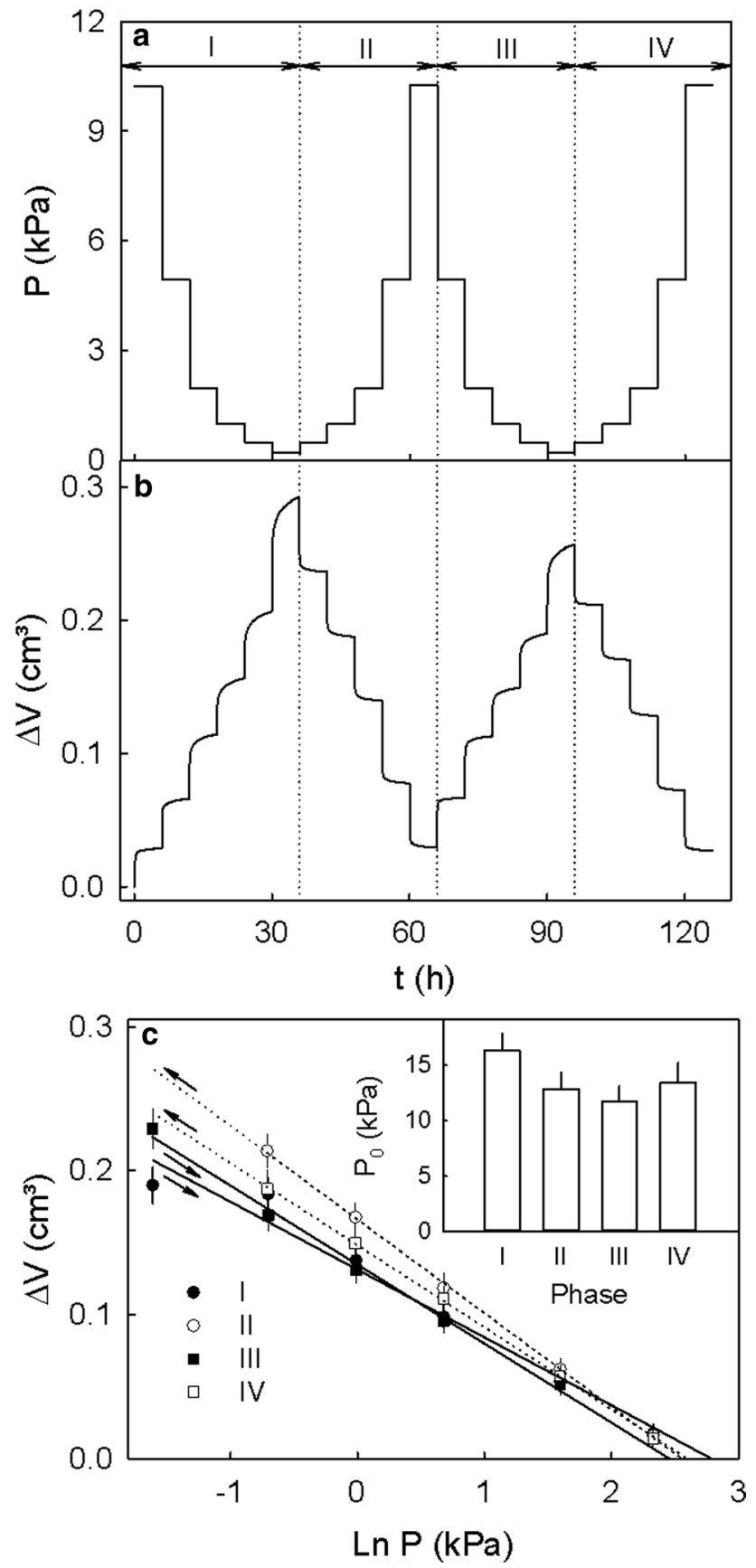

Fig. 4 Effect of ascending and descending pressures on the swelling of extracted cell walls of mature 'Staccato' sweet cherry when incubated in deionized water. Swelling was quantified as the change in volume $(\Delta V)$ at different pressures $(P)$ using a custom-built pressure chamber. a, b Time course of (a) descending (phases I, III) and ascending pressures (phases II and IV) and (b) corresponding changes in volume of extracted cell walls $(\Delta V)$. Horizontal arrows in a indicate the four consecutive phases I to IV of the experiment. During phases I and III pressure was decreased stepwise, during phases II and IV pressure was increased. c Relationship between the swelling of cell walls at equilibrium and the natural logarithm of the applied pressure in phases I to IV. Inset: swelling pressures $\left(P_{0}\right)$ during phases I, II, III and IV. The $P_{0}$ corresponds to the pressure at which no swelling occurs. Data in $\mathbf{b}$ represent a single replicate, those in $\mathbf{c}$ means $\pm \mathrm{SE}, n=3$
Interestingly, when ES were incubated in sweet cherry juice extracted from the same batch of fruit, marked swelling of cell walls occurred after turgor release by a freeze/thaw treatment (Table 5). The increase in cell wall thickness following turgor release was large when ES were incubated in juice extracted from the same batch of fruit at the natural $\mathrm{pH}$ 3.9. Adjusting the $\mathrm{pH}$ of the juice to a value comparable to that of the MES control, markedly reduced cell wall swelling to values even lower than in the MES control. Compared to natural juice at natural $\mathrm{pH}$, artificial juice prepared using the five major osmolytes present in sweet cherries had a low $\mathrm{pH}$ and an even larger effect on cell wall swelling following freeze/thaw turgor release. As in the natural juice, the effect on swelling decreased markedly to below the control values following the $\mathrm{pH}$ adjustment.

There was little difference in cell wall thickness of ES incubated in a range of organic acids, compared to the swelling of cell walls incubated in an MES-buffered control (Table 6). The only exception was in oxalic acid that caused significantly more swelling than in the control.

The $\mathrm{pH}$ of the incubation solution had a marked effect on cell wall thickness and swelling in the absence of turgor (Fig. 8). Relationships were biphasic. Cell wall thickness and swelling were essentially independent of $\mathrm{pH}$ between $\mathrm{pH}$ 8.0 and $\mathrm{pH}$ 5.0. Then, as $\mathrm{pH}$ decreased from $\mathrm{pH} 5.0$ to $\mathrm{pH}$ 2.0, swelling increased markedly (Fig. 8a, b). The breakpoint of the biphasic relationship was calculated to be $\mathrm{pH}$ 5.2. The buffer used to adjust $\mathrm{pH}$ also had a significant effect on cell wall swelling (Fig. 8c). Swelling was greatest in citric acid buffer, intermediate in phosphate, MES or TRIS buffer and the water control, and it was least in HEPES.

There was no cell wall swelling when ES were then incubated in $99.8,87.5$ or $75 \%$ ethanol (Fig. 9a). As the ethanol concentration decreased below $75 \%$, cell wall swelling increased and reached a maximum when the ES was incubated in deionized water (no ethanol). When an ES was transferred from aqueous ethanol to water or to $99.8 \%$ ethanol, the ES now incubated in water had fully swollen cell walls regardless of the ethanol concentration during the phase I of the experiment. Meanwhile, those now incubated in $99.8 \%$ ethanol were all non-swollen regardless of the initial ethanol concentration during the first phase of the experiment (Fig. 9b). When determining the effect of the ethanol concentration on the swelling capacity of the AIR prepared from the same batch of fruit, the swelling capacity decreased linearly as ethanol concentrations increased (Fig. 9c). There was a close and linear relationship between the swelling capacity of extracted cell walls and the swelling quantified microscopically using ES (Fig. 9c, inset). The regression equation was: $\mathrm{SC}\left(\mathrm{ml} \mathrm{g}^{-1}\right)=82.65$ $( \pm 1.79)-0.63( \pm 0.03) \times$ Thickness $(\mu \mathrm{m}) ; R^{2}=0.99 * * *$. 
Table 1 Thickness and swelling ( $\Delta$ thickness) of anticlinal epidermal cell walls of the epidermis of mature sweet and sour cherry fruit of various cultivars before ('+ turgor') and after incubation for $48 \mathrm{~h}$ in deionized water ('- turgor')

\begin{tabular}{|c|c|c|c|c|c|c|}
\hline \multirow[t]{2}{*}{ Fruit cultivar } & \multirow[t]{2}{*}{ Mass (g) } & \multirow{2}{*}{$\begin{array}{l}\text { Osmolarity } \\
\left(\mathrm{mmol} \mathrm{kg}^{-1}\right)\end{array}$} & \multicolumn{2}{|c|}{ Thickness $(\mu \mathrm{m})$} & \multicolumn{2}{|c|}{$\Delta$ Thickness } \\
\hline & & & + turgor & - turgor & $\mu \mathrm{m}$ & $\%$ increase \\
\hline Achat & $6.2 \pm 0.2$ & $1252 \pm 15$ & $3.5 \pm 0.2 \mathrm{a}^{\mathrm{a}}$ & $5.3 \pm 0.2 \mathrm{a}$ & $1.8 \pm 0.2$ & 50 \\
\hline Burlat & $10.8 \pm 0.5$ & $1230 \pm 59$ & $2.2 \pm 0.1 \mathrm{bd}$ & $5.4 \pm 0.2 \mathrm{ab}$ & $3.2 \pm 0.2$ & 144 \\
\hline Dönissens Gelbe & $5.7 \pm 0.2$ & $1232 \pm 46$ & $3.2 \pm 0.1 \mathrm{ac}$ & $5.8 \pm 0.1 \mathrm{ab}$ & $2.6 \pm 0.2$ & 83 \\
\hline Fabiola & $13.0 \pm 0.2$ & $1227 \pm 28$ & $2.4 \pm 0.1 \mathrm{bd}$ & $5.4 \pm 0.1 \mathrm{ab}$ & $3.0 \pm 0.2$ & 126 \\
\hline Hedelfinger & $9.2 \pm 0.1$ & $1284 \pm 40$ & $3.1 \pm 0.1 \mathrm{c}$ & $6.0 \pm 0.2 b$ & $3.0 \pm 0.2$ & 97 \\
\hline Kordia & $8.4 \pm 0.4$ & $991 \pm 36$ & $2.6 \pm 0.1 \mathrm{bc}$ & $5.9 \pm 0.1 \mathrm{ab}$ & $3.3 \pm 0.1$ & 126 \\
\hline Morellenfeuer & $5.7 \pm 0.2$ & $1006 \pm 42$ & $2.3 \pm 0.1 \mathrm{bd}$ & $5.0 \pm 0.2 \mathrm{ac}$ & $2.8 \pm 0.2$ & 125 \\
\hline Regina & $9.8 \pm 0.6$ & $1271 \pm 82$ & $2.6 \pm 0.1 \mathrm{~b}$ & $5.6 \pm 0.2 \mathrm{ab}$ & $3.1 \pm 0.2$ & 121 \\
\hline Sam & $10.1 \pm 0.5$ & $1456 \pm 85$ & $2.5 \pm 0.1 \mathrm{bd}$ & $5.5 \pm 0.2 \mathrm{ab}$ & $3.0 \pm 0.2$ & 124 \\
\hline Samba & $8.8 \pm 0.1$ & $1089 \pm 35$ & $2.1 \pm 0.1 \mathrm{bd}$ & $4.5 \pm 0.1 \mathrm{c}$ & $2.4 \pm 0.1$ & 114 \\
\hline Staccato & $8.10 \pm 0.2$ & $1117 \pm 79$ & $2.8 \pm 0.1 \mathrm{c}$ & $6.9 \pm 0.2 \mathrm{~d}$ & $4.2 \pm 0.2$ & 150 \\
\hline Grand mean & $8.7 \pm 0.7$ & $1196 \pm 41$ & $2.7 \pm 0.1$ & $5.6 \pm 0.2$ & $2.9 \pm 0.2$ & 114 \\
\hline
\end{tabular}

Swelling was calculated as the cell wall thickness after incubation, minus that before incubation. All fruit were grown in the field in the 2015 growing season. 'Achat' and 'Morellenfeuer' are sour cherries, all the others are sweet cherries. Data are means \pm SE, $n=10$ for mass and osmolarity, $n=40$ for cell wall thickness

${ }^{a}$ Mean separation within columns by Tukey's Studentized range test, $p<0.05$
Increasing the temperature from 4 to $23{ }^{\circ} \mathrm{C}$ slightly increased cell wall swelling by $3.6 \pm 0.2 \mu \mathrm{m}$ at $4{ }^{\circ} \mathrm{C}$ and by $4.3 \pm 0.2 \mu \mathrm{m}$ at $23^{\circ} \mathrm{C}$.

Following a freeze/thaw treatment, incubation of ES in PEG solutions induced cell wall swelling. For a particular size of PEG molecule, decreasing (more negative) the osmotic potential, caused a decrease in cell wall swelling, compared to the fully swollen control (Fig. 10a). The osmotic potential at half maximum swelling $\left(\psi_{\pi 50}\right)$ was calculated from the relationship between cell wall thickness and PEG solution osmotic potential. The value for $\Psi_{\pi 50}$ decreased exponentially as the molar mass of the PEG molecules increased (Fig. 10b). Interestingly, a common relationship for the different PEG molecules at the different osmotic potentials was obtained when cell wall thickness was expressed as a function of the number of ethylene glycol units in solution across all PEGs and across all osmotic potentials (Fig. 10c). Cell wall swelling increased markedly at low ethylene glycol concentrations (i.e. below 50 units ethylene glycol kg-1). In concentrations above 50 units of ethylene glycol kg-1 , there were no changes in cell wall swelling.

\section{Discussion}

Our experiments establish several important findings.
1. Significant cell wall swelling occurs in mature sweet cherry fruit as indexed by microscopy of skin sections, by determinations of the swelling capacity or by the swelling pressure of extracted cell walls;

2. Cell wall swelling is a physical process resulting from the release of cell turgor.

\section{Characterizing swelling using microscopy of skin sections, determinations of the swelling capacity or using a pressure chamber}

Microscopy of skin sections, assessment of their swelling capacity and swelling pressure, established that there is significant swelling of cell walls in mature sweet cherry fruit. Furthermore, correlation analysis demonstrated that in vivo swelling (as quantified by microscopy on ES) and in vitro swelling (as indexed by determinations of the swelling capacity in AIR) were significantly and positively related across a range of ethanol concentrations. Sweet cherry belongs to that group of fruit species characterized by their possession of a 'soft and melting' texture for which cell wall swelling during ripening is typical (Redgwell et al. 1997).

In our research, we used different cultivars and production sites to extend the experimental season. Because sweet cherry is a highly perishable crop, fruit of anyone cultivar is available at the optimal stage of commercial maturity only for a few days. The change of cultivars is, therefore, mandatory, if compromises in fruit quality (for example due to the 

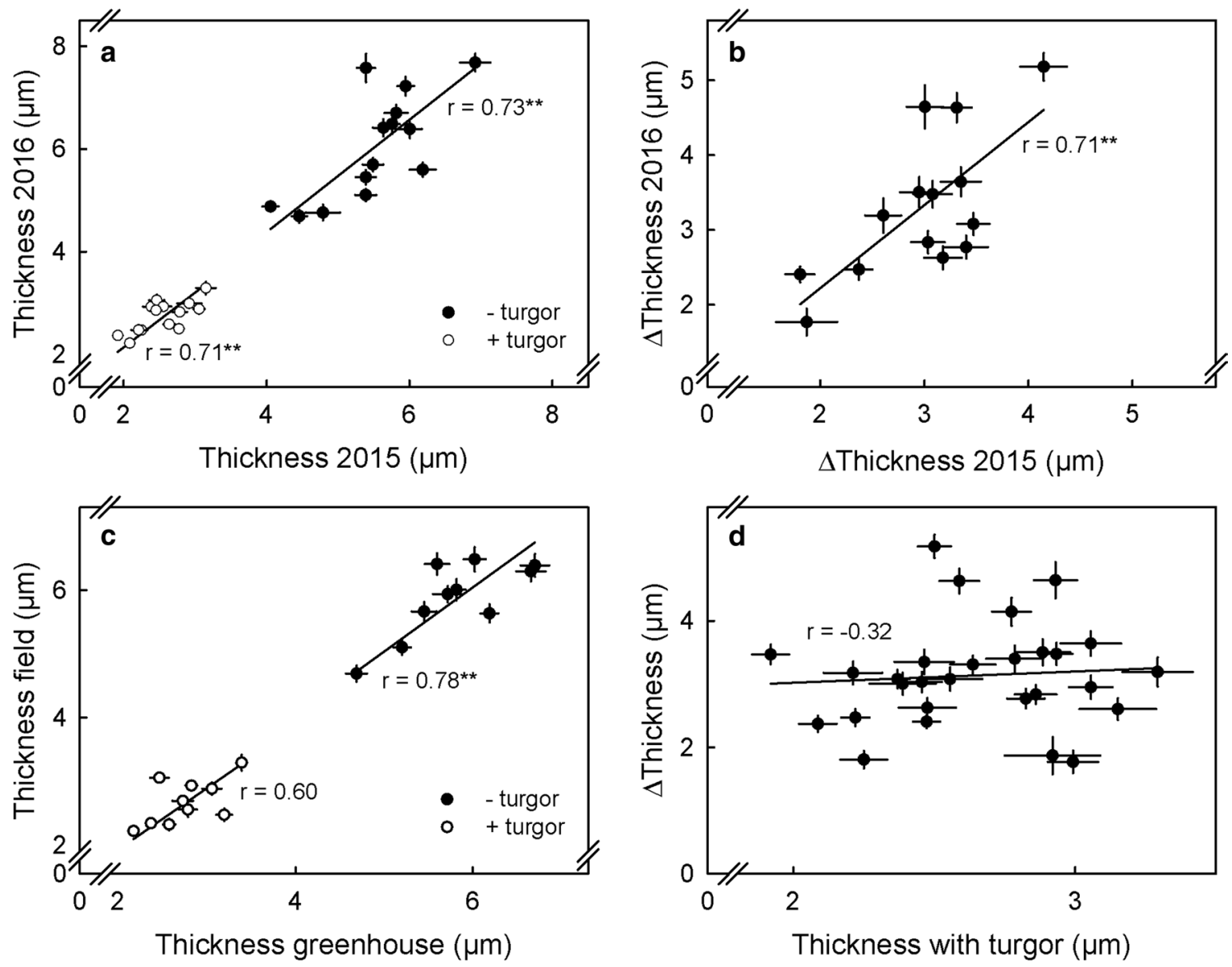

Fig. 5 a, b Relationship between thickness (a) or $\Delta$ thickness (swelling, b) of anticlinal epidermal cell walls of skin sections of 14 sweet cherry cultivars over two consecutive growing seasons. Data points represent means \pm SE $(n=40)$. c, d Relationship between thickness (c) or $\Delta$ thickness (d) of anticlinal epidermal cell walls of skin sections of ten sweet cherry cultivars grown in a greenhouse or in the

Table 2 Thickness and swelling ( $\Delta$ thickness) of anticlinal epidermal cell walls of skin sections excised from different positions on the surface of 'Lapins' sweet cherry fruit following incubation in deionized water

\begin{tabular}{llll}
\hline Position & \multicolumn{2}{l}{ Thickness $(\mu \mathrm{m})$} & \multirow{2}{*}{$\Delta$ Thickness $(\mu \mathrm{m})$} \\
\cline { 2 - 3 } & + turgor & - turgor & \\
\hline Cheek & $2.6 \pm 0.1 \mathrm{a}^{\mathrm{a}}$ & $4.3 \pm 0.1 \mathrm{a}$ & $1.7 \pm 0.1$ \\
Suture & $2.6 \pm 0.1 \mathrm{a}$ & $4.5 \pm 0.1 \mathrm{a}$ & $1.9 \pm 0.2$ \\
Stylar scar & $2.7 \pm 0.1 \mathrm{a}$ & $5.7 \pm 0.1 \mathrm{~b}$ & $3.0 \pm 0.2$ \\
Shoulder & $2.8 \pm 0.1 \mathrm{a}$ & $4.5 \pm 0.1 \mathrm{a}$ & $1.7 \pm 0.1$ \\
\hline
\end{tabular}

Swelling was calculated as the difference in cell wall thickness after release of turgor ('- turgor'), minus that before release of turgor ('+turgor'). Data present means $\pm \mathrm{SE}, n=40$

${ }^{a}$ Mean separation within columns by Tukey's Studentized range test, $p<0.05$

field under a rain-shelter. The change in cell wall thickness ( $\Delta$ thickness) was $48 \mathrm{~h}$ after the release of turgor by a freeze/thaw treatment. Skin sections were incubated in $10 \mathrm{mM}$ MES buffered deionized water at $\mathrm{pH} 5.8$. The $\Delta$ thickness was calculated as the thickness of swollen cell walls (without turgor, '- turgor') minus that of cells with turgor ('+turgor'). Data points represent means $\pm \operatorname{SE}(n=40)$

use of immature or overmature fruit) were to be avoided. The change of cultivars ensures that our findings are not limited to a specific cultivar, but are applicable to all cherries investigated. The data obtained indicate that swelling was reproducible among genotypes, seasons and environments (i.e. green house or rain shelter in the field) suggesting a high level of genetic control. Considerable differences exist in cell wall thickness and in the amount of swelling between cultivars. The reasons for these differences are unknown but may be related to one or both of the following: (i) Swelling differs between cell wall constituents and cell wall constituents differ between cultivars. In particular, pectins and/or xyloglucans may be involved (Brummell 2006). (ii) In an earlier study, we observed marked decreases in cell wall swelling in the presence of free $\mathrm{Ca}$ ions (Brüggenwirth and Knoche 2017). In contrast, swelling increased in the 
Table 3 Effect of turgor release on the thickness and swelling ( $\Delta$ thickness) of anticlinal cell walls of epidermal cells of skin sections (ES) of 'Sam' sweet cherry fruits following incubation in deionized water

\begin{tabular}{llll}
\hline Treatment & \multicolumn{2}{l}{ Thickness $(\mu \mathrm{m})$} & \multirow{2}{*}{$\Delta$ Thickness $(\mu \mathrm{m})$} \\
\cline { 2 - 3 } & + turgor & - turgor & \\
\hline Frost & $2.8 \pm 0.1 \mathrm{a}^{\mathrm{a}}$ & $5.6 \pm 0.2 \mathrm{ab}$ & $2.9 \pm 0.2$ \\
Heat & $2.7 \pm 0.1 \mathrm{a}$ & $5.8 \pm 0.2 \mathrm{a}$ & $3.1 \pm 0.2$ \\
Plasmolysis & $2.8 \pm 0.1 \mathrm{a}$ & $5.1 \pm 0.2 \mathrm{ab}$ & $2.3 \pm 0.2$ \\
Solvent & $2.7 \pm 0.1 \mathrm{a}$ & $5.6 \pm 0.2 \mathrm{ab}$ & $2.8 \pm 0.2$ \\
SDS & $2.9 \pm 0.1 \mathrm{a}$ & $4.9 \pm 0.3 \mathrm{~b}$ & $2.0 \pm 0.3$ \\
Control & $2.7 \pm 0.1 \mathrm{a}$ & $5.2 \pm 0.1 \mathrm{ab}$ & $2.5 \pm 0.1$ \\
\hline
\end{tabular}

Turgor was released by a freeze/thaw treatment, or by heating fruit to $60{ }^{\circ} \mathrm{C}$ for $1 \mathrm{~h}$, or plasmolyzing by incubation in $2.5 \mathrm{M}$ glucose for $24 \mathrm{~h}$, or by destroying membranes by incubation in acetone or in $20 \mathrm{mM}$ sodium dodecyl sulfate (SDS) for $48 \mathrm{~h}$. Incubation of ES for $48 \mathrm{~h}$ in $10 \mathrm{mM}$ MES buffer served as control. Swelling was calculated as the cell wall thickness after release of turgor ('- turgor') minus that before release of turgor ('+turgor'). Data presented are means $\pm \mathrm{SE}, n=40$

aMean separation within columns by Tukey's Studentized range test, $p<0.05$

presence of malic acid, probably due to extraction of $\mathrm{Ca}$ from the cell wall. Hence, differences may exist between cultivars in the uptake of $\mathrm{Ca}$ and in its adsorption to the cell wall constituents.

Fig. 6 a Micrographs of the effect of the osmotic potential of sucrose solutions on cell wall thickness and plasmolysis of excised 'Staccato' epidermal skin sections. Deionized water (osmotic potential $0 \mathrm{MPa}$ ) served as control. Bar $=20 \mu \mathrm{m}$. b, $\mathbf{c}$ The effect of the osmotic potential of sucrose solutions on the thickness of epidermal cell walls of skin sections (b) and the percentage of plasmolyzed cells (c). Dotted horizontal lines indicate cell wall thickness at 100, 50 and $0 \%$ cell wall swelling (b) and at $50 \%$ plasmolysis (c), the dashed vertical lines indicate the osmotic potentials at $50 \%$ cell wall swelling (b) and at $50 \%$ plasmolysis (c). The arrow indicates the osmotic potential of the fruit $(-2.6 \pm 0.1 \mathrm{MPa})$. The equation for the sigmoid regression model describing the relationship between cell wall thickness and osmotic potential was: Thickness $(\mu \mathrm{m})=$ Thickness with turgor $(\mu \mathrm{m})+\frac{a}{-\left(\frac{\text { osmotic potential }(\mathrm{MPa})-x_{0}}{b}\right)_{\text {, }}}$.

The maximum thickness (upper asymptote) was calculated as the average cell wall thickness of all treatments with fully swollen cell walls (without turgor, $5.8 \pm 0.2 \mu \mathrm{m}$ ), the minimum thickness (lower asymptote) as the average thickness of all treatments with non-swollen cell walls (with turgor, $2.7 \pm 0.1 \mu \mathrm{m})$. The regression equation for the relationship between the percentage of plasmolyzed cells and the osmotic potential was: Plasmolysis $(\%)=\frac{a}{\left(\text { osmotic potential }(\mathrm{MPa})-x_{0}\right)}$. The osmotic $-\left(\frac{\text { osmotic potential }(\mathrm{MPa})-x_{0}}{b}\right)$. The osmotic potentials of the sucrose solutions at half maximum thickness of the epidermal cell walls $(-2.0 \mathrm{MPa})$ and at $50 \%$ plasmolysis of epidermal cells $(-1.3 \mathrm{MPa})$ were calculated from the respective regression equations. Data in $\mathbf{b}$ and $\mathbf{c}$ represent means \pm SE, $n=40$ for $\mathbf{b}, n=20$ for $\mathbf{c}$
From a practical point of view the question arises as to whether cell wall swelling and cracking susceptibility are closely correlated. Unfortunately, there is no comprehensive study on cracking susceptibility published that assessed more than four of the cultivars investigated in our study. However, for a larger set of unpublished data from our group, there was no significant correlation between cell wall swelling and cracking susceptibility as indexed by the time to $50 \%$ cracking $(n=11, r=-0.04)$ or the water uptake required for $50 \%$ cracking $(n=11, r=-0.13$; Winkler, unpublished data). It is important to note, however, that the lack of such a relationship must not be interpreted as negative evidence. Swelling is only the final step in a series of events that ultimately leads to cracking.

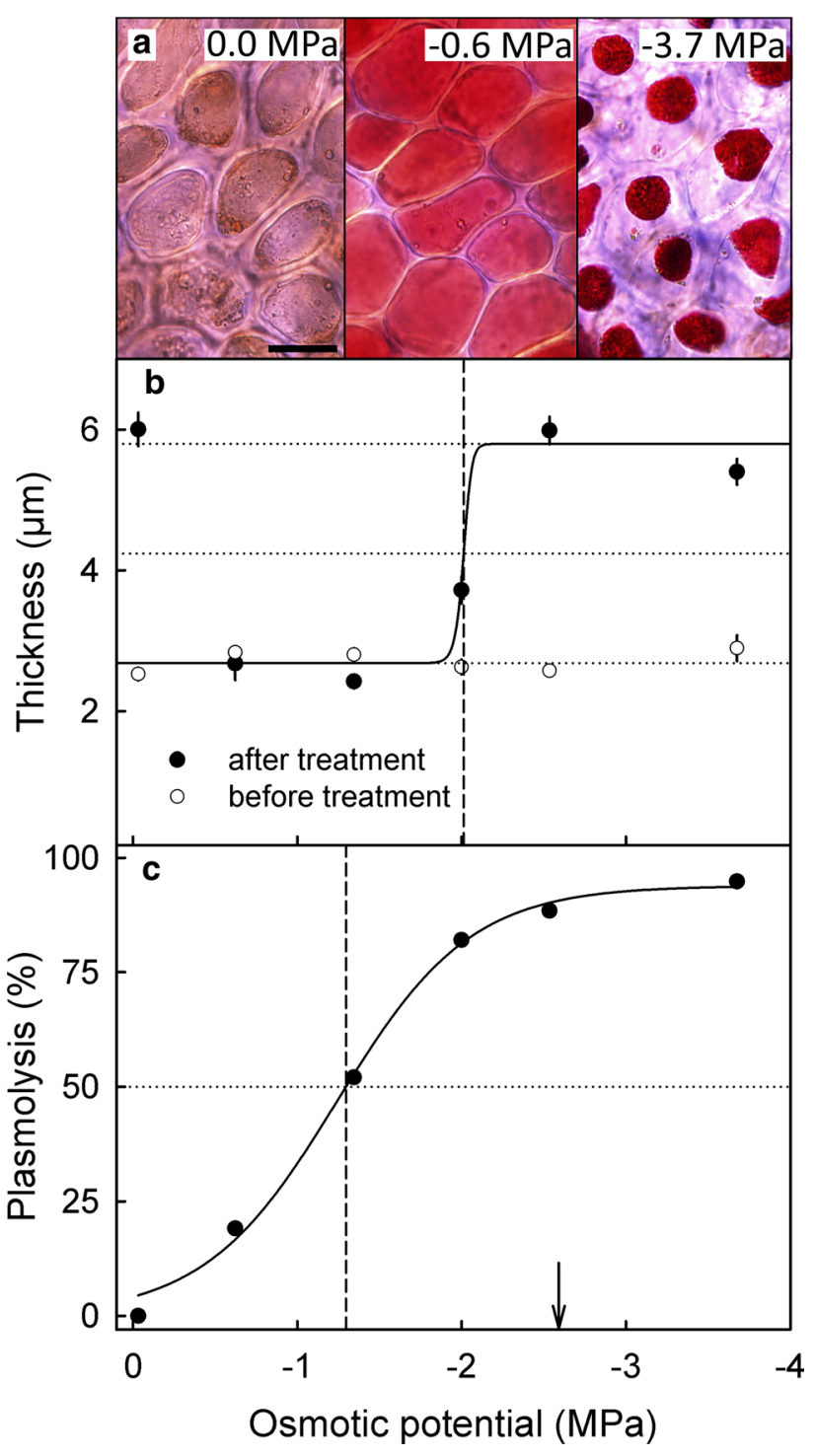


Table 4 Thickness of anticlinal epidermal cell walls of excised skin segments (ES) of 'Santina' sweet cherry fruit following incubation in hypotonic or hypertonic sucrose solutions. Incubation in water served as control

\begin{tabular}{llll}
\hline Treatment sequence & \multicolumn{4}{l}{ Thickness $(\mu \mathrm{m})$} \\
\cline { 2 - 4 } Phase I/Phase II & Initial & Phase I & Phase II \\
\hline Control/control & $2.5 \pm 0.2 \mathrm{a}^{\mathrm{a}}$ & $3.9 \pm 0.2 \mathrm{~b}^{*}$ & $4.0 \pm 0.2 \mathrm{~b}^{*}$ \\
Hypotonic/hypotonic & $2.7 \pm 0.1 \mathrm{a}$ & $2.8 \pm 0.1 \mathrm{a}$ & $2.9 \pm 0.1 \mathrm{a}$ \\
Hypotonic/hypertonic & $2.5 \pm 0.1 \mathrm{a}$ & $2.7 \pm 0.1 \mathrm{a}$ & $3.7 \pm 0.1 \mathrm{~b}^{* *}$ \\
Hypertonic/hypotonic & $2.7 \pm 0.1 \mathrm{a}$ & $4.8 \pm 0.2 \mathrm{~b}^{* *}$ & $2.8 \pm 0.1 \mathrm{a}$ \\
Hypertonic/hypertonic & $2.5 \pm 0.1 \mathrm{a}$ & $4.3 \pm 0.2 \mathrm{~b}^{* *}$ & $4.3 \pm 0.2 \mathrm{~b}^{* *}$ \\
\hline
\end{tabular}

Treatments were applied sequentially. Following establishment of thickness immediately after excision (Initial), phase I and phase II treatments were applied for $22 \mathrm{~h}$ each and thicknesses quantified. Data present mean \pm SE, $n=40$

${ }^{a}$ Mean separation within rows by Tukey's Studentized range test, $p<0.05$. The symbol *indicates that cells collapsed as indexed by the loss of anthocyanins and the presence of a coagulated cytoplasm, **indicates plasmolyzed vital cells. In all other treatments cells were vital without plasmolysis

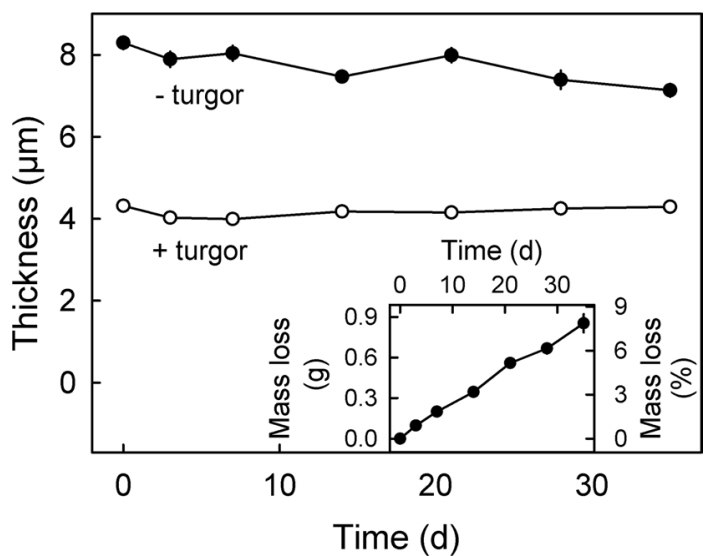

Fig. 7 Effect of storage duration of mature 'Merchant' sweet cherry fruit on swelling of anticlinal epidermal cell walls of skin sections following the release of turgor by a freeze/thaw treatment and a $48 \mathrm{~h}$ incubation period in $10 \mathrm{mM}$ MES buffered deionized water at $\mathrm{pH}$ 5.8 ('- turgor'). Cell wall thickness before the freeze/thaw treatment served as control ('+turgor'). Inset: mass loss of whole fruit during storage. Whole fruit were held for up to 35 days at $2{ }^{\circ} \mathrm{C}$ and $95 \%$ relative humidity before skin sections were excised and incubated to quantify cell wall swelling. Data represent means \pm SE, $n=40$ for main graph, $n=10$ for inset

\section{Swelling is a physical process resulting from loss of cell turgor}

Cell wall swelling is a physical process resulting from the release of pressure on the cell wall due to loss of cell turgor (in most cases associated with cell death). This hypothesis is supported by the following arguments:
First, the magnitude of the pressure generated by extracted cell wall material and the turgor pressure in mature sweet cherry parenchyma cells are of the same order of magnitude (Knoche et al. 2014; Schumann et al. 2014; Grimm et al. 2019). Hence, it is plausible that cell turgor balances and (and thus prevents) cell wall swelling in turgid cells. We recognize that the cell wall swelling pressure and cell turgor are both negligibly low relative to the very negative osmotic potential of juice extracted from sweet cherry fruit. Hence, cell wall swelling does not contribute significantly to fruit water potential (which is the sum of a number of water potential components-including osmotic, pressure, matric, etc.).

Second, pressurizing and depressurizing cell walls resulted in corresponding changes in volume of the swollen cell wall and in nearly identical swelling pressures indicating that cell wall swelling was completely reversible.

Third, the release of cell turgor (realized in this study through a number of quite different and unrelated treatments) always resulted in a similar level of cell wall swelling. We did, however, note some significant (but minor) differences in wall swelling depending on the chemical nature of the organic acid or buffer used. For example, more wall swelling was observed with citric or oxalic acid. This was probably due to complexing with $\mathrm{Ca}$ ions, which altered the amount of bound $\mathrm{Ca}$ in the cell wall matrix. Removal of $\mathrm{Ca}$ from the cell wall will result in reduced cross-linking, thus a loosening of cell wall constituents, and thus an increase in swelling (Brüggenwirth and Knoche 2017).

Fourth, in vital cells, incubation in hypertonic solutions caused plasmolysis and cell wall swelling. There was no swelling in hypotonic solutions provided that cells remained vital and turgescent. Furthermore, upon transferring cells from a hypertonic to hypotonic solution cells deplasmolysed and cell wall swelling was completely reversed. In the water, control cells lost vitality and turgor and hence, cell walls swelled. These observations support the idea of a role for turgor in cell wall swelling. However, while over a small range of osmotic potential (between -0.6 and $-1.3 \mathrm{MPa}$ ) cells began to plasmolyze, we could detect no corresponding increase cell wall swelling. The reason for this discrepancy is unknown but it may be related to a non-uniform distribution of osmotic potential within the tissue (Grimm and Knoche 2015) and/or to different kinetics of plasmolysis and cell wall swelling.

Fifth, incubation of ES in a concentration series of aqueous ethanol resulted in less or even no swelling at high ethanol concentrations. This effect is familiar to light microscopists, being associated with tissue dehydration during fixation. As expected for a physical process, the effects of ethanol on cell wall swelling were simply reversible. 
Table 5 Effect of expressed juice and artificial juice, without and with $\mathrm{pH}$ adjustment on the thickness and swelling ( $\Delta$ thickness) of anticlinal epidermal cell walls of 'Adriana' sweet cherry fruit

\begin{tabular}{|c|c|c|c|c|c|}
\hline \multirow[t]{2}{*}{ Treatment } & \multirow{2}{*}{$\begin{array}{l}\text { Concentra- } \\
\text { tion }(\mathrm{mmol} \\
\left.\mathrm{kg}^{-1}\right)\end{array}$} & \multirow{2}{*}{$\mathrm{pH}$} & \multicolumn{2}{|c|}{ Thickness $(\mu \mathrm{m})$} & \multirow{2}{*}{$\begin{array}{l}\Delta \text { Thickness } \\
(\mu \mathrm{m})\end{array}$} \\
\hline & & & + turgor & - turgor & \\
\hline Control & 10 & 5.8 & $2.6 \pm 0.1 \mathrm{a}^{\mathrm{a}}$ & $5.5 \pm 0.1 \mathrm{a}$ & $2.9 \pm 0.2$ \\
\hline Juice & 663 & 3.9 & $2.6 \pm 0.1 \mathrm{a}$ & $6.5 \pm 0.2 \mathrm{~b}$ & $4.0 \pm 0.3$ \\
\hline $\begin{array}{l}\text { Juice } \mathrm{pH} \\
\text { adjusted }\end{array}$ & 675 & 6.3 & $2.5 \pm 0.1 \mathrm{a}$ & $4.7 \pm 0.1 \mathrm{c}$ & $2.2 \pm 0.2$ \\
\hline $\begin{array}{l}\text { Artificial } \\
\text { juice }\end{array}$ & 665 & 3.9 & $2.7 \pm 0.1 \mathrm{a}$ & $7.8 \pm 0.2 \mathrm{~d}$ & $5.0 \pm 0.3$ \\
\hline $\begin{array}{l}\text { Artificial } \\
\text { juice } \mathrm{pH} \\
\text { adjusted }\end{array}$ & 671 & 6.4 & $2.7 \pm 0.1 \mathrm{a}$ & $4.9 \pm 0.1 \mathrm{c}$ & $2.2 \pm 0.2$ \\
\hline
\end{tabular}

Swelling was calculated as the cell wall thickness after release of turgor ('- turgor') minus that before release of turgor ('+ turgor'). Deionized water served as control. Data presented are means \pm SE, $n=40$. Artificial juice (containing glucose, fructose, sorbitol and potassium malate) was prepared at the same osmolarity as the juice expressed from the fruit. NB These five osmolytes represent the major components of sweet cherry fruit, accounting for around $98 \%$ of juice osmolarity (Herrmann 2001)

${ }^{a}$ Mean separation within columns by Tukey's Studentized range test, $p<0.05$

Table 6 Thickness and swelling ( $\Delta$ thickness) of anticlinal epidermal cell walls of excised skin segments (ES) of 'Adriana' sweet cherry fruit before and after incubation in solutions of citric, tartaric, malic or oxalic acid (all at $20 \mathrm{mM}$ )

\begin{tabular}{lllll}
\hline Treatment & $\mathrm{pH}$ & \multicolumn{2}{l}{ Thickness $(\mu \mathrm{m})$} & \multirow{2}{*}{$\Delta$ Thickness $(\mu \mathrm{m})$} \\
\cline { 2 - 4 } & & + turgor & - turgor & \\
\hline Control & 5.9 & $2.5 \pm 0.1 \mathrm{ab}^{\mathrm{a}}$ & $5.2 \pm 0.1 \mathrm{a}$ & $2.7 \pm 0.1$ \\
Citric acid & 4.8 & $2.4 \pm 0.1 \mathrm{ab}$ & $5.7 \pm 0.2 \mathrm{ab}$ & $3.2 \pm 0.2$ \\
Tartaric acid & 4.5 & $2.4 \pm 0.1 \mathrm{ab}$ & $5.6 \pm 0.2 \mathrm{a}$ & $3.3 \pm 0.2$ \\
Malic acid & 4.9 & $2.3 \pm 0.1 \mathrm{a}$ & $5.7 \pm 0.2 \mathrm{ab}$ & $3.4 \pm 0.2$ \\
Oxalic acid & 4.4 & $2.4 \pm 0.1 \mathrm{ab}$ & $6.2 \pm 0.2 \mathrm{~b}$ & $3.8 \pm 0.2$ \\
Ascorbic acid & 5.5 & $2.6 \pm 0.1 \mathrm{~b}$ & $5.4 \pm 0.1 \mathrm{a}$ & $2.8 \pm 0.1$
\end{tabular}

MES buffer at $10 \mathrm{mM}$ served as control. Swelling was calculated as the cell wall thickness after release of turgor ('- turgor') minus that before release of turgor (' + turgor'). Data present mean \pm SE, $n=40$

${ }^{a}$ Mean separation within columns by Tukey's Studentized range test, $p<0.05$

Lastly, for the PEG series investigated, there was no simple relationship between the solution osmotic potential and the extent of swelling. Interestingly, a close relationship across all PEG molecules and all osmotic potentials was obtained when swelling was expressed as a function of the number of ethylene glycol units. This observation was unexpected and may find its explanation in terms of the physicochemical interactions between PEG and water.
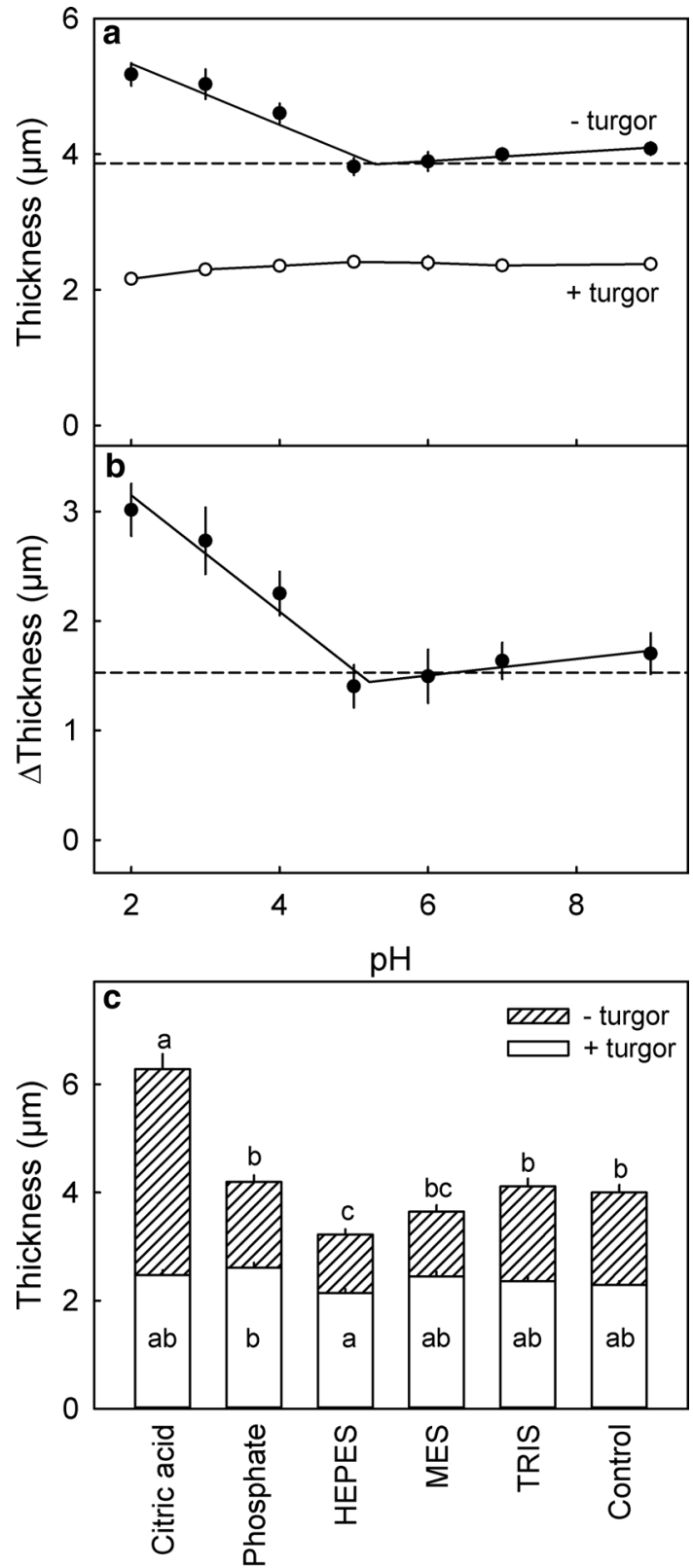

Buffer

Fig. 8 a, b Effect of $\mathrm{pH}$ on thickness (a) and swelling ( $\Delta$ thickness, b) of anticlinal epidermal cell walls of skin sections of 'Adriana' sweet cherry fruit. The dashed horizontal line indicates the cell wall thickness (a) and swelling of the cell wall (b) after a freeze/thaw treatment and subsequent incubation in $10 \mathrm{mM}$ MES buffered deionized water at pH 5.8. Swelling was calculated as the cell wall thickness after releasing turgor by a freeze/thaw treatment and subsequent incubation in solutions of different $\mathrm{pH}$ (" - turgor') minus that before ('+ turgor'). c Effect of different buffer systems at pH 6.7 on thickness of anticlinal epidermal cell walls before and after releasing turgor by a freeze/thaw treatment and subsequent incubation in the buffer solutions. The effect of the buffer was established on the same batch of fruit as that used in a, b. Skin sections incubated in deionized water served as control. Mean separation in $\mathbf{c}$ by Tukey's Studentized range test, $p<0.05$. Data represent means $\pm \mathrm{SE}, n=40$ 
PEG is an amphiphilic molecule that binds to the cell wall, thereby physically blocking the surface and preventing swelling. Binding, and hence blockage, will increase with the molecular weight of the PEG molecule and with PEG concentration. In addition, the direct binding of water by the PEG molecules will reduce swelling. The molar ratio of water molecules bound to ethylene glycol units is up to 2:1 (Makogon and Bondarenko 1985; Lüsse and Arnold 1996). Water bound to ethylene glycol units (in contrast to free water) does not participate in the swelling process. Both effects explain why swelling should be related to the number of ethylene glycol units, and not related to the osmotic potential of the PEG solution.

The effect of $\mathrm{pH}$ on swelling is consistent with literature data on tomato cell walls (MacDougall et al. 2001; MacDougall and Ring 2003). It is also supported by the hypothesis of turgor control of swelling. Pectins are a potential candidate for cell wall swelling. They represent weak polyelectrolytes cross-linked by divalent $\mathrm{Ca}$ ions. The $\mathrm{pKa}$ of the uronic acid moiety of galacturonic acid is $\mathrm{pH} 3.5$ (Kohn and Kovac 1978). As pH decreases, dissociation decreases and so will the Ca-content of the cell wall (and hence cell wall cross-linking) (MacDougall et al. 2001). This is expected to result in greater cell wall swelling. Extraction and complexing of $\mathrm{Ca}$ would also account for differential swelling among buffers of different chemistry but of the same $\mathrm{pH}$. Additional indirect evidence for the involvement of pectins in swelling comes from (i) the exposure of pectins on the fracture surface of the sweet cherry fruit skin (Schumann et al. 2019), (ii) the mode of fracture of the skin along and not across cell walls (Brüggenwirth and Knoche 2017) and (iii) data on other fruit crops demonstrating that swelling is associated with the pectin fraction (Redgwell et al. 1997; Basanta et al. 2013).

Interestingly, expansins show a similar response of cell wall loosening to variation of $\mathrm{pH}$ as the cell wall swelling in our study (Cosgrove 1998). Whether they contributed to cell wall swelling in sweet cherry at low $\mathrm{pH}$, is unknown. In the normal $\mathrm{pH}$ range, a role of expansins in swelling is unlikely. Because expansins are proteins, they should have been inactivated by heat, surfactant or solvent treatments summarized in Table 3. These, however, did not differ in swelling from the control.

\section{Conclusion}

Our results demonstrate that cell wall swelling in mature sweet cherry fruit is substantially a physical process. In a healthy cell, the wall swelling is countered by cell turgor. The pressure generated by cell wall swelling is very low relative to the very negative osmotic potential of the juice.
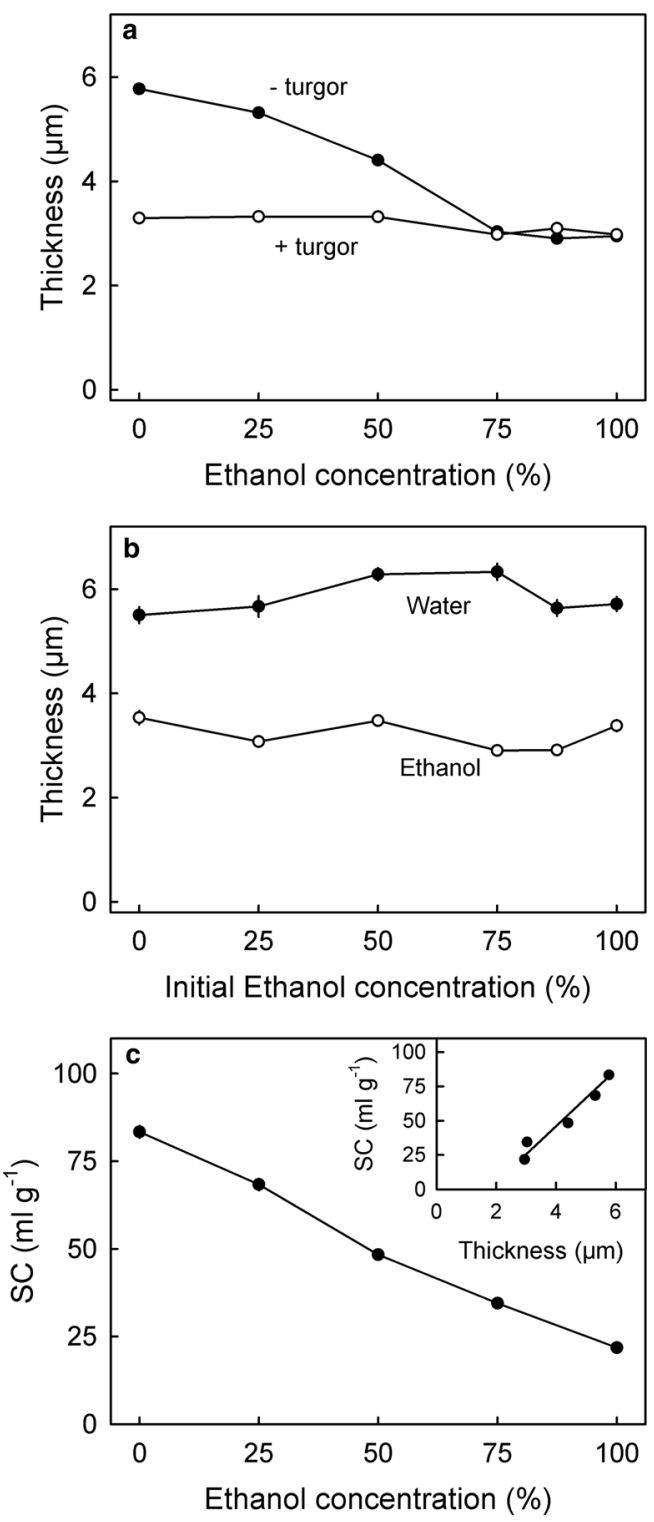

Fig. 9 Effect of the concentration of ethanol on the thickness of anticlinal epidermal cell walls of skin sections of mature 'Sweetheart' sweet cherry. a Effect of incubating skin sections in aqueous ethanol. Cell wall thickness was quantified before ('+turgor') and after release of turgor by the ethanol treatment ('- turgor'). b Reversibility of the effect of ethanol on swelling of cell walls. The reversibility was studied by replacing the aqueous ethanol solution from (a) by deionized water ('Water') or by $100 \%$ ethanol ('Ethanol'), as the incubation solution. $\mathbf{c}$ Effect of ethanol concentration on the swelling capacity (SC) of an extracted cell wall preparation from fruit of the same batch. Inset: relationship between the swelling capacity of extracted cell walls and the cell wall thickness of swollen cell walls (without turgor) as determined by microscopy (see data in a). The coefficient of correlation was $r=0.98^{* * *}$. Data represent means $\pm \mathrm{SE}, n=40$ for $\mathbf{a}$ and $\mathbf{b}, n=3$ for $\mathbf{c}$

We do not yet know which fraction(s) of the cell wall are responsible for swelling. Nevertheless, we suggest that pectins and, possibly, xyloglucans are likely candidates. 

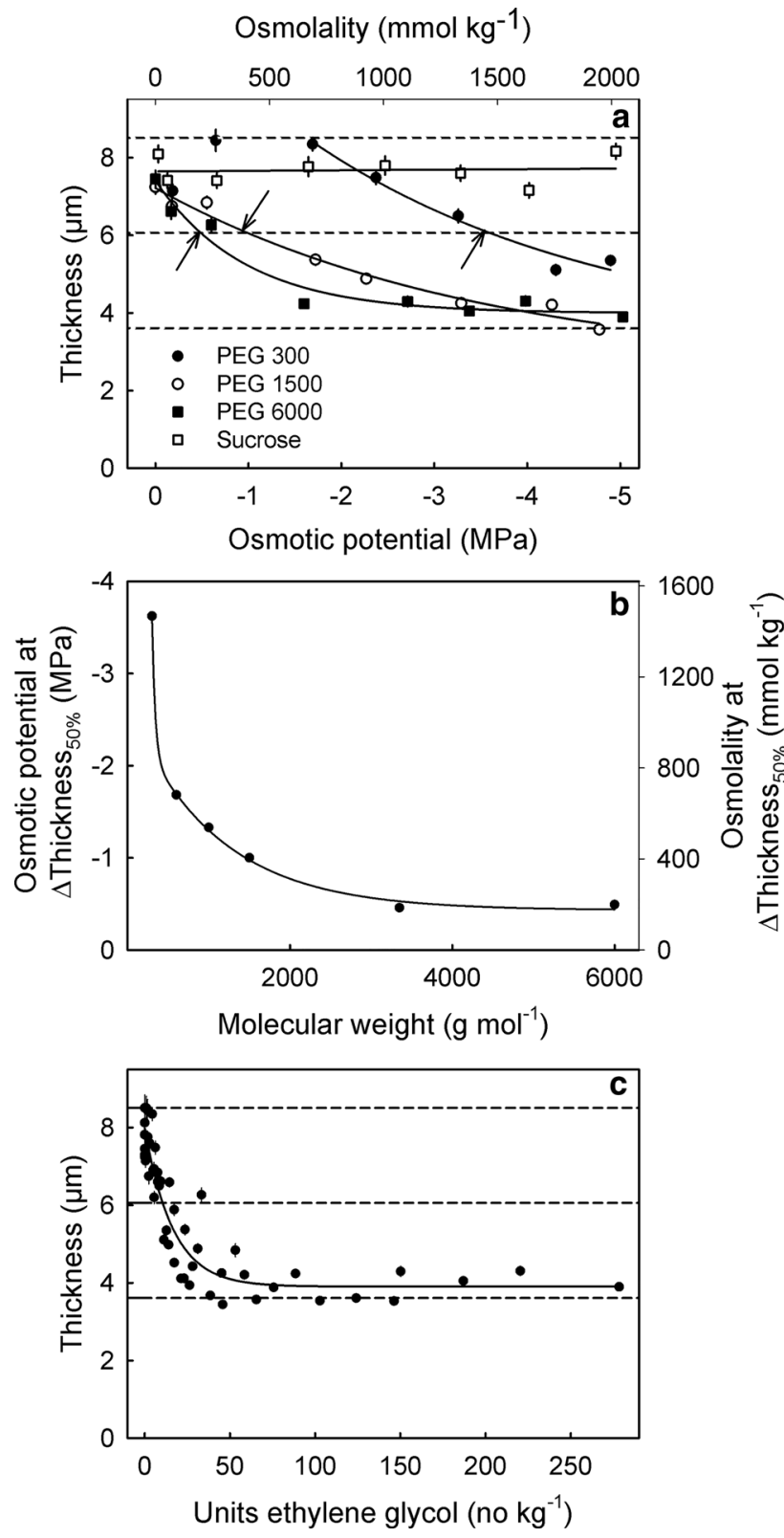

Fig. 10 Effect of osmotic potential of polyethylene glycol (PEG) solutions of different molar masses on the thickness of anticlinal epidermal cell walls of 'Staccato' sweet cherry. Mean molar mass of PEGs were 300 (PEG 300), 1500 (PEG 1500) and $6000 \mathrm{~g} \mathrm{~mol}^{-1}$ (PEG 6000). The lower dashed horizontal line indicates the mean cell wall thickness of skin sections before treatment, the upper dashed line the maximum swelling after releasing turgor by a freeze/thaw treatment (averaged across all treatments). Half maximum swelling is indicated by the dashed horizontal line in the middle. Sucrose solutions of the respective osmotic potentials served as control. b Relationship between the osmotic potential at $50 \%$ cell wall swelling and the molar mass of the PEGs. The osmotic potential at $50 \%$ swelling was calculated as the intercept of the regression line with the line for half maximum swelling (middle horizontal dashed line in a, intercept indicated by arrows). $\mathbf{c}$ The regression model was Thickness $(\mu \mathrm{m})=y_{0}+a e^{b * \text { osmotic potential (MPa) }}$ for the relationship of thickness of cell walls and osmotic potential and Thickness $(\mu m)=y_{0}+a e^{-b * \text { units ethylene glycol } * \mathrm{~kg}^{-1}}$ for that between thickness of cell walls and the number of units ethylene glycol. Data represent means \pm SE, $n=40$ for a and $\mathbf{c}$
We expect that further study will reveal which cell wall fractions are responsible for swelling. The effects of $\mathrm{Ca}$ ions on cell wall swelling also warrant further study. Field applications of $\mathrm{Ca}$ may prove a useful tool for decreasing susceptibility of soft fruit species to rain cracking.

\section{Author contribution statement}

CS and MK conceived and designed the experiments. CS conducted the measurements and analysed the data. CS and MK wrote the manuscript. All authors read and approved the manuscript.

Acknowledgements Open Access funding provided by Projekt DEAL. We thank Andreas Meyer for constructing the pressure chamber, Simon Sitzenstock for technical help, Drs. Chong Cheng and Eli Ruckenstein for useful discussion of the PEG effect and Dr. Alexander Lang for useful comments on an earlier version of this manuscript. This study was funded in part by a grant from the German Science Foundation (DFG).

\section{Compliance with ethical standards}

Conflicts of interest The authors declare that they have no conflict of interest.

Open Access This article is licensed under a Creative Commons Attribution 4.0 International License, which permits use, sharing, adaptation, distribution and reproduction in any medium or format, as long as you give appropriate credit to the original author(s) and the source, provide a link to the Creative Commons licence, and indicate if changes were made. The images or other third party material in this article are included in the article's Creative Commons licence, unless indicated otherwise in a credit line to the material. If material is not included in the article's Creative Commons licence and your intended use is not permitted by statutory regulation or exceeds the permitted use, you will need to obtain permission directly from the copyright holder. To view a copy of this licence, visit http://creativecommons.org/licenses/by/4.0/.

\section{References}

Alkio M, Jonas U, Sprink T, van Nocker D, Knoche M (2012) Identification of putative candidate genes involved in cuticle formation in Prunus avium (sweet cherry) fruit. Ann Bot 110:101-112

Andersen PC, Richardson DG (1982) A rapid method to estimate fruit water status with special reference to rain cracking of sweet cherries. J Am Soc Hort Sci 107:441-444

Basanta MF, de Escalada Pla MF, Stortz CA, Rojas AM (2013) Chemical and functional properties of cell wall polymers from two cherry varieties at two developmental stages. Carbohydr Polym 92:830-841

Basanta MF, Nora MA, Ponce ML, Salum MD, Raffo AR, Vicente REB, Stortz CA (2014) Compositional changes in cell wall polysaccharides from five sweet cherry (Prunus avium L.) cultivars during on-tree ripening. J Agr Food Chem 62:12418-12427

Brüggenwirth M, Knoche M (2017) Cell wall swelling, fracture mode, and the mechanical properties of cherry fruit skins are closely related. Planta 245:765-777 
Brummell DA (2006) Cell wall disassembly in ripening fruit. Funct Plant Biol 33:103-119

Considine JA, Kriedemann PE (1972) Fruit splitting in grapes. Determination of the critical turgor pressure. Austr J Agr Res 23:17-24

Cosgrove DJ (1998) Cell wall loosening by expansins. Plant Physiol 118:333-339

Grimm E, Knoche M (2015) Sweet cherry skin has a less negative osmotic potential than the flesh. J Am Soc Hort Sci 140:472-479

Grimm E, Hahn J, Pflugfelder D, Schmidt M, van Dusschoten D, Knoche M (2019) Localized bursting of mesocarp cells triggers catastrophic fruit cracking. Hort Res 6:79

Herrmann K (2001) Inhaltsstoffe von Obst und Gemüse. Ulmer, Stuttgart

Knoche M, Peschel S (2006) Water on the surface aggravates microscopic cracking of the sweet cherry fruit cuticle. J Am Soc Hort Sci 131:192-200

Knoche M, Winkler A (2017) Rain-induced cracking of sweet cherries. In: Quero-García J, Iezzoni A, Puławska J, Lang G (eds) Cherries: botany, production and uses. CAB International, Wallingford, pp $140-165$

Knoche M, Beyer M, Peschel S, Oparlakov B, Bukovac MJ (2004) Changes in strain and deposition of cuticle in developing sweet cherry fruit. Physiol Plant 120:667-677

Knoche M, Grimm E, Schlegel HJ (2014) Mature sweet cherries have low turgor. J Am Soc Hort Sci 139:3-12

Kohn R, Kovac P (1978) Dissocation constants of D-galacturonic and D-glucuronic acid and their O-methyl derivatives. Chemické Zvesti 32:478-485

Lüsse S, Arnold K (1996) The interaction of poly(ethylene glycol) with water studied by $1 \mathrm{H}$ and $2 \mathrm{H}$ NMR relaxation time measurements. Macromolecules 29:4251-4257

MacDougall AJ, Ring SG (2003) The hydration behaviour of pectin networks and plant cell walls. In: Voragen F, Schols H, Visser $\mathrm{R}$ (eds) Advances in pectin and pectinase research. Springer, Dordrecht, pp 123-135

MacDougall AJ, Rigby NM, Ryden P, Tibbits CW, Ring SG (2001) Swelling behavior of the tomato cell wall network. Biomacromol $2: 450-455$
Makogon BP, Bondarenko TA (1985) The hydration of polyethylene oxide and polyacrylamide in solution. Polym Sci USSR 27:630-634

Measham PF, Bound SA, Gracie AJ, Wilson SJ (2009) Incidence and type of cracking in sweet cherry (Prunus avium L.) are affected by genotype and season. Crop Pasture Sci 60:1002-1008

Peschel S, Knoche M (2005) Characterization of microcracks in the cuticle of developing sweet cherry fruit. J Am Soc Hort Sci 130:487-495

Raghavendra SN, Rastogi NK, Raghavarao KSMS, Tharanathan RN (2004) Dietary fiber from coconut residue: effects of different treatments and particle size on the hydration properties. Eur Food Res Technol 218:563-567

Redgwell RJ, MaxRae E, Hallett I, Fischer M, Perry J, Harker R (1997) In vivo and in vitro swelling of cell walls during fruit ripening. Planta 203:162-173

Schumann C, Schlegel HJ, Grimm E, Knoche M, Lang A (2014) Water potential and its components in developing sweet cherry. J Am Soc Hort Sci 139:349-355

Schumann C, Winkler A, Brüggenwirth M, Köpcke K, Knoche M (2019) Crack initiation and propagation in sweet cherry skin: a simple chain reaction causes the crack to 'run'. PLoS ONE 14(7):e0219794. https://doi.org/10.1371/journal.pone.0219794

Sekse L, Bjerke KL, Vangdal E (2005) Fruit cracking in sweet cherries-An integrated approach. Acta Hort 667:471-474

Sozzi GO, Greve LC, Prody GA, Labavitch JM (2002) Gibberellic acid, synthetic auxins, and ethylene differentially modulate alpha-Larabinofuranosidase activities in antisense 1-aminocyclopropane1-carboxylic acid synthase tomato pericarp discs. Plant Physiol 129:1330-1340

Winkler A, Ossenbrink M, Knoche M (2015) Malic acid promotes cracking of sweet cherry fruit. J Am Soc Hort Sci 140:280-287

Winkler A, Peschel S, Kohrs K, Knoche M (2016) Rain cracking in sweet cherries is not due to excess water uptake but to localized skin phenomena. J Am Soc Hort Sci 141:653-660

Publisher's Note Springer Nature remains neutral with regard to jurisdictional claims in published maps and institutional affiliations. 